\title{
INTERESES SOCIALES PROTEGIDOS \\ A TRAVÉS DEL BIEN JURÍDICO-PENAL DEL DELITO \\ DE PUBLICIDAD ENGAÑOSA
}

\author{
Samuel Rodríguez Ferrández \\ Universidad de Murcia \\ E-mail: samuel.rodriguez@,um.es
}

\begin{abstract}
RESUMEN: Este artículo pretende describir los contenidos de los diferentes intereses sociales implicados en la persecución penal de la publicidad engañosa, que no son otros que el mercado, la libre y leal competencia dentro del mismo y, por último, los derechos de los consumidores y usuarios. Tal tarea se acomete con la ayuda del examen de las normas nacionales e internacionales que configuran el marco de referencia para la protección jurídica de tales intereses. Tras ello, se esboza cuáles son los diferentes perfiles del concreto contenido del bien jurídico penalmente protegido en el delito de publicidad engañosa en el Código Penal español y, finalmente, se concluye argumentadamente acerca de la legitimidad material de la decisión adoptada en su día por el legislador en orden a la persecución penal de comportamientos mendaces en la publicidad de productos ofertados en el mercado a los consumidores.
\end{abstract}

Palabras clave: publicidad engañosa, bien jurídico, libre competencia, derechos de los consumidores.

\begin{abstract}
This paper aims to describe the contents of the different social interests involved in the criminal prosecution of deceptive advertising, which are the market, free and fair competition within it and, finally, the rights of consumers and users. This task is undertaken with the help of the examination of the national and international norms that configure the frame of reference for the legal protection of such interests. After that, the different profiles of the specific content of the criminally protected legal asset in the crime of deceptive advertising in the Spanish Penal Code are outlined and, finally, it is argued to conclude on the material legitimacy of the decision adopted years ago by the legislator in order to criminally prosecute mendacious behaviours in the advertising of products offered in the market to consumers.
\end{abstract}

Keyword: deceptive advertising, legal asset, free competition, consumers rights. 
SUMARIO: I. BREVE INTRODUCCIÓN A LA PROGRESIVA IMPORTANCIA DE LA ACTIVIDAd PUbLICITARIA. II. LOS INTERESES SOCIALES IMPLICADOS EN LA PERSECUCIÓN PENAL DE LA PUBLICIDAD ENGAÑOSA: MERCADO, COMPETENCIA Y CONSUMIDORES. 2.1. Introducción: la adopción de la decisión legislativa para criminalizar la publicidad engañosa. 2.2. Referente normativo: la Constitución Económica o el "Derecho Económico Constitucional". 2.3. La libertad de empresa y la libre (y leal) competencia. 2.4. La libertad de empresa y la protección del consumidor. 2.5. Libre (y leal) competencia, protección del consumidor y actividad publicitaria. 2.6. Conclusión: el delito de publicidad engañosa como delito económico relativo al mercado y a los consumidores. III. CONTENIDO DEL BIEN JURÍDICO-PENAL PROTEGIDO EN EL ARTÍCULO 282 CP 1995. IV. CONSIDERACIONES FINALES. V. BIbLIOGRAFÍA.

\section{BREVE INTRODUCCIÓN A LA PROGRESIVA IMPORTANCIA DE LA ACTIVIDAD PUBLICITARIA}

Hay quien analiza la historia de la publicidad dividiéndola en tres grandes períodos: 1.La era de la premercadotecnia, 2.- la era de la comunicación masiva y 3.- la era de la investigación ${ }^{1}$. Dejando de lado el primero de ellos, nos centraremos en el análisis del segundo. El evento que condiciona este escalón en la evolución de la actividad publicitaria es la Revolución Industrial ${ }^{2}$, que supuso la introducción de una serie de innovaciones tecnológicas que proporcionaron un vertiginoso aumento de la producción industrial. Así, la publicidad nacerá, tal y como es hoy concebida, "promovida por la necesidad de dar salida a los productos elaborados en la fábrica, y se desarrollará gracias a las innovaciones técnicas en la imprenta, la prensa y el cartel, que sustituyen definitivamente a los antiguos procedimientos de información comercial (el pregón y el charlatán, sobre todo)"3. También es conveniente apuntar que las nuevas doctrinas económicas ${ }^{4}$ ofrecieron el substrato ideológico al desarrollo de este proceso histórico. Y es que, en lo que atañe a la actividad publicitaria, se dice que la doctrina del librecambio y la idea de la competencia como ele-

1 El primero de los períodos abarcaría desde el inicio de los intercambios en tiempos prehistóricos, hasta mediados del siglo XVIII (cuando aparecieron los primeros anuncios impresos). En él, los medios publicitarios fundamentales eran las tablas de barro, los pregoneros de los pueblos y los letreros de las tabernas. El segundo es situado cronológicamente a partir del siglo XVIII hasta principios del siglo XX. Por último, en el tercero, que vendría a comprender los últimos cincuenta años, los publicistas han centrado su actividad en la búsqueda de la "campaña publicitaria perfecta" (que vendría a ser aquella que logre incidir de forma casi automática en el comportamiento de los individuos, lindando materialmente con los postulados de la Ciencia Conductista), ayudados de los avances de la tecnología moderna. Es en esta época en la que la publicidad se consolida como una fuerza económica y social importante (Kleppner, O.: Publicidad (traducido por Georgina Greenham del Castillo), Prentice Hall, 1994 (12 edición), pág. 4).

2 Cuando hablamos de "Revolución Industrial" nos referimos a la acontecida en Inglaterra, "La Primera Revolución Industrial", cuyo inicio sitúan la mayoría de los historiadores en torno al año 1750, si bien se suele acotar de un modo más preciso su cronología entre los años 1785 y 1820-25 por autores como Arnold J. Toynbee (Lectures on the Industrial Revolution in England, Kessinger, 2010). Podemos recomendar para el estudio de este acontecimiento histórico la lectura de dos trabajos: el primero, que se constituye en obra de referencia sobre el tema, realizado por el "historiador social" Hobsbawm, E.J., bajo el título Industria e Imperio. Una historia económica de Gran Bretaña desde 1750 (traducido por Gonzalo Pontón, Ariel Historia, 1982 (2 edición)) y, el segundo, siguiendo un criterio más “compendiador", realizado por la profesora Deane, P., bajo el título La Primera Revolución Industrial (traducido por Jordi Solé-Tura, Península, 1998 ( $9^{\mathrm{a}}$ edición)).

3 Sánchez Guzmán, J.R.: Breve historia de la publicidad, Pirámide, 1973, pág. 34.

4 Primero la fisiocracia y, después, los denominados "economistas clásicos", representados principalmente por Adam Smith y David Ricardo. Y es que, del mismo modo que en el ámbito político las justificaciones ideológicas del Absolutismo fueron sustituidas por las del Liberalismo, en el ámbito económico, el Mercantilismo se vio superado por las justificaciones doctrinales del lema fisiócrata, posteriormente elevado a postulado del Liberalismo económico, "laissez faire, laissez passer, le monde va de lúi même” (“dejad hacer, dejad pasar, el mundo marcha por sí solo"). 
mento motor de la economía, facilitaron el desarrollo de las técnicas publicitarias, sobre todo con el objetivo de "vender una producción que había alcanzado cotas importantes"5. En definitiva, puede afirmarse que el fin primordial de la actividad publicitaria tras esta fase histórica no es más que tratar de erigirse en un medio o instrumento para la relación entre productor y consumidor, entre oferente y demandante, de la que resultaría el beneficio económico del primero y el mayor bienestar del segundo.

A comienzos del siglo XX, de la misma manera que el capitalismo de libre competencia entraría en una nueva fase en la que predominarían las situaciones monopolistas ${ }^{6}$, la publicidad comenzaría a desempeñar un importante papel en este nuevo contexto, que será facilitado y potenciado por la incidencia de dos factores en su evolución ${ }^{7}$ : a.- El desarrollo de los medios de comunicación de masas (cine, radio, televisión, etc.), como soportes de comunicación utilizados para la difusión de sus mensajes. b.- Las conquistas teóricas de las denominadas Ciencias Humanas (psicología, sociología, lingüística, etc.), que ayudarían al perfeccionamiento progresivo de los métodos de elaboración del mensaje publicitario. Es en esta tercera etapa cuando los mecanismos publicitarios comienzan a ser enfocados hacia aquél objetivo, fundamentalmente comercial, de despertar en los individuos "el impulso de compra", de estimular en ellos la propensión al consumo en detrimento del ahorro ${ }^{8}$.

Este proceso evolutivo ha dado lugar a que, en la actualidad, la publicidad aparezca configurada como un sistema de signos diferenciado y como un modo de comunicación específico dentro del amplio contexto de la comunicación de masas. Por ello, se ha visto necesitada de una teoría que la sistematizara como ciencia, carencia que parece haber subsanado gracias a la denominada "teoría de la información". Es ésta la que ha logrado formular una definición - científica - de publicidad como "un mensaje seleccionado del total de la información sobre un producto susceptible de ser transmitida y que, mediante unos códigos y unos soportes específicos, se dirige a unos receptores con la intención de provocar en ellos un cambio de comportamiento"9.

5 O, dicho con otras palabras, "[...] librecambio y competencia rigen la nueva situación económica y con ello comienza a estimularse la actividad publicitaria" (Sánchez Guzmán, J.R.: Breve historia ... ob. cit., págs. 38 - 39).

6 Situadas fuera del inalcanzable modelo de "competencia perfecta" que pretendía aquél.

7 Sánchez Guzmán, J.R.: Breve historia ... ob. cit., pág. 41.

8 Sánchez Guzmán, J.R., Breve historia... ob. cit., pág. 42. Se puede observar en este punto una destacable coincidencia evolutiva de la publicidad con la propaganda gubernamental, pues es precisamente en esta época (comienzos del pasado siglo) cuando los gobiernos (sobre todo el de los Estados Unidos) comienzan a hacer uso de la propaganda política para orientar, a su conveniencia, el sentido de la opinión pública (véase en este sentido Chomsky, N. y Ramonet, I.: Cómo nos venden la moto, Icaria, 2001, págs. 8 y ss.).

9 Sánchez Guzmán, J.R.: Breve historia... ob. cit., pág. 146. A partir de esta definición, se pueden extraer los nueve elementos básicos que intervienen en el proceso de comunicación publicitaria: 1.- El emisor: la fuente de la comunicación publicitaria y que es llamado también, genéricamente, "anunciante". 2.- El mensaje: el contenido de la comunicación publicitaria, el "qué" del anuncio, la información que transmite del producto entre todas las posibles que puede transmitir. 3.- La codificación: la forma de transmitir el mensaje o el "cómo" elaborar la información seleccionada del producto. 4.- El significante: que, en el ámbito de la comunicación publicitaria, viene a ser el soporte en queda plasmado o contenido el mensaje publicitario (p. ej. el "spot" de televisión, la cuña radiofónica, etc.). 5.- El canal: el vehículo utilizado para la transmisión, que es el rol desempeñado por los medios de comunicación de masas. 6.- El "significante reactivado": que hace referencia al valor añadido al significante, fundamentalmente conseguido gracias a su ubicación formal en el canal (p. ej. horario de máxima audiencia en televisión, página impar de revista o periódico) y a la composición material del anuncio (de cara a incidir en la percepción del receptor). 7.- El receptor: el público al que van dirigidos los mensajes. 8.- El descodificador: que es el mismo receptor, pero en su vertiente de "descifrador" del mensaje para comprenderlo. 9.- La "retroalimentación" o respuesta al mensaje: la cual no reviste nunca la forma de diálogo entre el emisor y el receptor, sino que aparece en términos de actuación o de opinión (Sánchez Guzmán, J.R.: Breve historia ... ob. cit., págs. 146 - 149). 
En nuestro tiempo, el importante impulso que han experimentado las innovaciones tecnológicas ha permitido un correlativo desarrollo en las técnicas de elaboración de tales "códigos o soportes", con lo que la capacidad actual de influencia de la publicidad sobre el comportamiento de los consumidores se ha visto incrementada hasta límites que rozan, no sólo la ilegalidad (pues el Derecho no siempre "está al día" en estas cuestiones en tanto se ve relegado a tratarlas a posteriori ${ }^{10}$ ) sino, incluso, lo inmoral (aunque entrar en este plano es siempre "peligroso" cuando de estudiar jurídicamente un tema se trata). Del mismo modo, no es difícil imaginar la importancia cuantitativa que la publicidad ha adquirido en el marco de la actividad económica; este dato es evidente si examinamos lo que las distintas empresas gastan en dar a conocer sus productos a los consumidores, lo cual nos permite deducir, sin ir más lejos, que los empresarios valoran la publicidad como un activo de notoria importancia.

Así pues, configurada la publicidad como una disciplina con sustantividad propia dentro de la teoría de la información, y resaltado su papel capital en el plano económico dentro de la sociedad actual, concebida como "sociedad de consumo"11, puede encontrar explicación la necesidad latente de regularla y limitarla en el marco político-legal en su faceta instrumental, esto es, como "herramienta" utilizada por los empresarios para dirigirse a los consumidores, con el fin de "convencerlos" para que adquieran sus productos, y no aquellos otros ofertados por sus competidores.

\section{LOS INTERESES SOCIALES IMPLICADOS EN LA PERSECUCIÓN PENAL DE LA PUBLICIDAD ENGAÑOSA: MERCADO, COMPETENCIA Y CONSUMIDORES}

\subsection{Introducción: la adopción de la decisión legislativa para criminalizar la publicidad engañosa}

Dentro del proceso de reforma del sistema penal español, que transcurría en paralelo a la evolución política ${ }^{12}$ (y económica) española determinada por la CE 1978, y en el que se antojaba necesario un Código Penal nuevo, llegó el Proyecto de Ley Orgánica de Código Penal de 1980 (PLOCP 1980), cuyo artículo 342 (algunos autores citan el art. 338), dentro de la Sección Segunda del Capítulo II, "De las infracciones de la propiedad industrial y

10 Roxin ha puesto de manifiesto en este sentido que las ciencias sociales (especialmente el Derecho y, más concretamente el Derecho Penal) se mueven en campos más difíciles de pronosticar que los de las ciencias naturales, "pues los avances en éstas se evidencian de manera lineal, uno sobre la base del otro; mientras que el desarrollo social se produce de manera dialéctica, puesto que las posiciones y las contraposiciones varían" (Morillas Cueva, L.: "Reflexiones sobre el Derecho Penal del futuro", en Revista Electrónica de Ciencia Penal y Criminología, núm. 4, 2002, citando al autor alemán).

11 Puede hablarse de una "sociedad de consumo", siguiendo a Rodríguez de Quiñones, considerando, en una "sociedad de masas" como la actual, la aparición "de una enorme masa de consumidores a los que se dirigen, para presionarlos y manipularlos en sus opciones en el mercado, las empresas a través de los medios masificados de publicidad o mediante técnicas individuales pero aplicadas, también, en masa" (Rodríguez de Quiñones y de Torres, A.: "La protección del consumidor en la Constitución española de 1978. Notas para un debate", en Revista General de Derecho, núms. 678 - 679, 2001, pág. 1.815).

12 Quintero Olivares, G. (y Morales Prats, F. (Colab.)): Parte General del Derecho penal, Aranzadi, 2005 (1 ${ }^{\text {a }}$ edición), pág. 224. 
derechos que conciernen a la competencia y a los consumidores", Título VIII, "Delitos contra el orden socioeconómico", venía a constituir el primer intento de introducción del delito de publicidad engañosa en nuestro país ${ }^{13}$. Pero el PLOCP 1980 nunca llegó a ser discutido en sede parlamentaria, pues el Gobierno de la "Unión de Centro Democrático" (UCD) lo retiró posteriormente. Más tarde, y aprovechando la "brecha reformadora" abierta por la LO 8/1983 de 25 de junio, "de Reforma Urgente y Parcial del Código Penal", el Ministerio de Justicia designó una Comisión que debía elaborar un nuevo Proyecto de Código; así, y tomando como base de los trabajos el anterior PLOCP 1980, llegó la Propuesta de Anteproyecto de Nuevo Código Penal de 1983 (PANCP 1983) ${ }^{14}$, que en su artículo 279 venía a regular el delito de publicidad engañosa en muy semejantes términos a los de su predecesor ${ }^{15}$.Y también el Anteproyecto de Código Penal de 1992 (APCP 1992) contemplaría el artículo 282.1, dentro del Capítulo XII, "De los delitos relativos a la propiedad industrial, el mercado y a los consumidores", del Título XII, "Delitos patrimoniales y contra el orden socioeconómico", como precepto antecesor más inmediato del actual delito de publicidad engañosa ${ }^{16 / 17}$. Finalmente, tras las elecciones generales de 1993, se presentó con la nueva legislatura el Anteproyecto de Código Penal de 1994, al que siguieron el Proyecto de Ley Orgánica de Código Penal de 1994, que, ahora en su artículo 278.1, venía a recoger íntegramente el texto reproducido anteriormente en el artículo 282.1 del APCP $1992^{18}$.

Finalmente, el Código Penal de 1995, aprobado el 8 de noviembre de 1995, comenzó a regular en su artículo 282 el delito de publicidad engañosa por primera vez en nuestro país, conforme a la siguiente dicción literal actualmente vigente:

"Serán castigados con la pena de prisión de seis meses a un año o multa de doce a veinticuatro meses los fabricantes o comerciantes que, en sus ofertas o publicidad de productos

13 Art. 342 PLOCP 1980: "1. El que intencionadamente hiciese en la actividad publicitaria falsas alegaciones sobre la naturaleza, composición, origen cualidades sustanciales de los productos o servicios anunciados, capaces por sí mismas de inducir a grave error al consumidor, será castigado con la pena de multa de tres a veinticuatro meses. 2. Se impondrá la pena en su mitad superior cuando se tratare de publicidad de sustancias alimentarias, medicamentos, viviendas u otros objetos de primera necesidad. 3. En todo caso se decretará la publicación de la sentencia en los periódicos oficiales y si el perjudicado lo solicitare, el Tribunal podrá autorizar la reproducción total o parcial en cualquier otro medio informativo".

14 Que tampoco alcanzó, por cierto, a ser debatida en sede parlamentaria (Quintero Olivares, G. (y Morales Prats, F. (Colab.)): Parte General... ob. cit., pág. 225).

15 Art. 279 PANCP 1983: "1. El que intencionadamente hiciere en la actividad publicitaria alegaciones falsas sobre la naturaleza, composición, virtudes o cualidades sustanciales de los productos o servicios anunciados, capaces por sí mismas de inducir a grave error al consumidor, será castigado con la pena de multa de tres a dieciocho meses. 2. Se impondrá la pena en su mitad superior cuando se tratare de publicidad de sustancias alimenticias, medicamentos, viviendas u otros objetos de primera necesidad o destinadas al consumo infantil. 3. El Tribunal, de oficio o a instancia de parte, decretará la publicación de la sentencia en los periódicos oficiales y, así mismo, podrá autorizar la reproducción total o parcial de la misma en cualquier otro medio de información".

16 Art. 282.1 APCP 1992: "Serán castigados con la pena de prisión de seis meses a un año o multa de seis a dieciocho meses los fabricantes o comerciantes que, en sus ofertas o publicidad de productos o servicios, hicieren alegaciones falsas o manifiesten características inciertas sobre los mismos, de modo que puedan perjudicar notoriamente a los consumidores o a los demás concurrentes en el mercado, sin perjuicio de la pena que corresponda aplicar por la comisión de otros delitos".

17 No obstante, cuando el APCP 1992 era ya Proyecto de Ley Orgánica del Código Penal (PLOCP 1992, contemplando en ese momento el mismo texto aquél, ahora en su artículo 287.1) y había recorrido la mitad de su tramitación parlamentaria, "las Cortes se disolvieron y el Proyecto decayó" (Quintero Olivares, G. (y Morales Prats, F. (Colab.)): Parte General... ob. cit., pág. 229).

18 Excepción hecha de la sustitución del término "notoriamente" por "notablemente". 
o servicios, hagan alegaciones falsas o manifiesten características inciertas sobre los mismos, de modo que puedan causar un perjuicio grave y manifiesto a los consumidores, sin perjuicio de la pena que corresponda aplicar por la comisión de otros delitos".

Se ha apuntado que los delitos agrupados en el Capítulo XI del Título XIII del CP 1995, en el que se incardina este artículo 282, tienen como elemento común a todos ellos la noción de competencia ${ }^{19}$, como soporte último del sistema económico correspondiente al modelo de "economía mixta" o "economía social de mercado" que se diseña en la CE $1978^{20}$. Como apunta Miró Llinares, la protección de la libre competencia por parte del denominado Derecho Penal Económico (a cuyas concepciones nos referiremos más adelante) "[...] está adquiriendo hoy singular importancia, correlativamente a la mayor conciencia por los Estados de su necesaria implicación en la regulación del libre mercado" ${ }^{21}$. Antes de entrar en el análisis de estas cuestiones, es necesario sentar unas premisas conceptuales previas en torno a las mismas. Para ello partiremos de una imprescindible referencia previa al denominado "orden económico constitucional" como referente normativo, deteniéndonos primero en el contenido y contornos delimitadores del mismo para, después, relacionarlos con la regulación jurídica de la actividad publicitaria y la intervención penal ofrecida en la materia.

\subsection{Referente normativo: la Constitución Económica o el "Derecho Económico Constitucional"}

El "orden económico constitucional” anteriormente mencionado puede ser concebido como "el conjunto de derechos y principios sobre los que debe desarrollarse la vida económica y la actividad empresarial en España"22, recogidos expresamente la CE 1978 (como a continuación veremos), y cuya salvaguardia se encarga a una función de policía específica ${ }^{23}$.

A este respecto, es de común opinión entre la doctrina mercantilista española el hecho de que "la Constitución española no es neutral ${ }^{24}$ ante la Economía y que, además,

19 La competencia económica ha sido descrita como "la situación de enfrentamiento y rivalidad que mantienen las empresas que concurren en el mercado, en virtud de la cual cada transacción comercial que efectúa cualquiera de ellas puede ser representada por las demás como una oportunidad comercial perdida" (Baylos Corroza, H.: Tratado

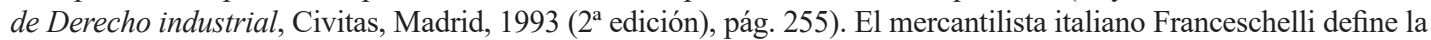
competencia -económica- más descriptivamente como "la situación en la que se encuentran actual o potencialmente dos o más empresarios que, operando en el mismo ámbito del mercado, ofrecen bienes y servicios susceptibles de satisfacer, incluso con medio (bienes y servicios) diferentes, la misma necesidad, y que se encuentran en una situación de conflicto de intereses frente a la clientela" (Broseta Pont, M.: Manual de Derecho Mercantil, 1994 (10ª edición), nota 2, pág. 125, citando Franceschelli, R.: Studi e capitoli sul diritto della concorrenza, Giuffrè, 1970).

20 González Rus, J.J.: "Delitos contra el patrimonio y contra el orden socioeconómico (VIII)", en Cobo del Rosal, M. (Dir.): Curso de Derecho penal. Parte Especial (I), Marcial Pons, 1996, pág. 768.

21 Miró Llinares, F.: La protección penal de la propiedad intelectual en la sociedad de la información, Dykinson, 2003, pág. 248.

22 Broseta Pont, M.: Manual de..., ob. cit., pág. 74. Diferente es el concepto de "orden público económico", que fue acuñado en nuestro Derecho por el civilista De Castro y Bravo, quien consideraba que el mismo era la aplicación al campo de la economía del concepto genérico de orden público recogido en el Código civil (De Castro y Bravo, F.: "Notas sobre las limitaciones intrínsecas de la autonomía de la voluntad. La defensa de la competencia. El orden público. La protección del consumidor", en Anuario de Derecho Civil, 1982, págs. 1.021 y ss.). Hace especial hincapié en distinguir "Orden económico" de "Constitución económica" Linde Paniagua, E.: Introducción al sistema económico en la Constitución Española, Cometa, 1987, págs. 7-10.

23 Menéndez Menéndez, A.: La competencia desleal, Real Academia de Jurisprudencia y Legislación, 1988, págs. y ss.

24 Es decir, "en España, como sucede en Alemania, existe una posición de 'neutralidad constitucional' respecto a la política económica. En otras palabras, se mantiene que la Constitución no establece un modelo determinado de 
no pergeña un 'sistema económico' $[\ldots]^{25}$, sino un 'modelo económico' que coincide con el moderno modelo capitalista, conocido como 'neoliberal', 'neocapitalista' o de 'economía social de mercado', el cual se caracteriza fundamentalmente por respetar la propiedad e iniciativas privadas, aunque atemperadas y sometidas a las exigencias implícitas en el 'Estado social y económico de Derecho' que establece la Constitución española, caracterizado, entre otras cosas, por el reconocimiento igualitario de la propiedad privada y de la iniciativa pública en lo económico (o libertad de empresa)"26.

De acuerdo con este auténtico "humus" ideológico y conceptual, se ha hablado de una "Constitución Económica" o "Derecho Económico Constitucional" para referirse al "conjunto de normas básicas destinadas a proporcionar el marco jurídico fundamental para la estructura y funcionamiento de la actividad económica - es decir- para el orden y el proceso económico"27. Dos son los principios fundamentales que informan ese conjunto normativo y que aparecen consagrados en la propia CE $1978^{28}$ : $1^{\circ}$.- La propiedad privada y, consecuentemente, también la de los medios de producción (art. 33.1 CE 1978); $2^{\circ}$.- La libertad de empresa en el sistema de la economía de mercado (art. 38 CE 1978) ${ }^{29}$, la cual se traduce: a) en la libertad de los empresarios para crear, dirigir y fijar las condiciones de desarrollo de su actividad y, b) en que los poderes públicos deben garantizar, además, que sea el mercado (es decir, la interacción o juego de la ley de la oferta y la demanda) el que fije o deba fijar las condiciones, precios calidades, etc., de los productos y servicios, si bien respetando los límites legales que la propia Constitución invoca y que las leyes deben desarrollar, tales como la libertad de competencia y la protección a los consumidores (art. 51 CE 1978).

\subsection{La libertad de empresa y la libre (y leal) competencia}

Es en este segundo principio fundamental recogido en el art. 38 CE 1978 (libertad de empresa), y en el primero de sus dos límites internos constitucionalmente trazados que

política económica" (Pérez del Valle, C.: "Introducción al Derecho Penal Económico", en Bacigalupo Zapater, E. (Dir.): Curso de Derecho Penal Económico, Marcial Pons, 1998, pág. 26) o, a sensu contrario, que la Constitución "permite la aplicación de cualquier programa político económico" (Bajo Fernández, M. y Bacigalupo Saggese, S.: Derecho penal económico, Centro de Estudios Ramón Areces, 2001 ( $1^{\text {a }}$ edición), pág. 21).

25 "[...] que es un esquema rígido difícilmente desarrollable por leyes" (Broseta Pont, M.: Manual de..., ob. cit., pág. 75).

26 Broseta Pont, M.: Manual de..., ob. cit., pág. 75.

27 Bajo Fernández, M. y Bacigalupo Saggese, S.: Derecho penal económico, ob. cit., pág. 19. También se ofrecen otras definiciones de "Constitución Económica", como la formulada por Font Galán, J.I.: Constitución económica y derecho a la competencia, Tecnos, 1987, y recogida por Rodríguez de Quiñones, según la cual sería aquel "[...] conjunto de normas de contenido específicamente socio-económico mediante las cuales se establecen los principios que rigen la actividad económica desarrollada por los individuos y por el Estado, y se determinan las libertades, derechos, deberes y responsabilidades de aquéllos y éste en el ejercicio de dicha actividad" (Rodríguez de Quiñones y de Torres, A.: "La protección del consumidor en...", ob. cit., pág. 1.804).

28 Si bien a ellos hay que unir tanto "el derecho de fundación y asociación para la realización y explotación de las actividades económicas que la ley declara lícitos (arts. 34 y 22 CE 1978)", como "el derecho a la libre elección de profesión (art. 35.1 CE 1978)" (Broseta Pont, M.: Manual de..., ob. cit., pág. 75).

29 Sobre sus orígenes, véase Conesa, F.: Libertad de empresa y Estado de Derecho, Rialp, 1978, págs. 17 y ss.; sobre su contenido en la CE 1978, véase Entrena Cuesta, R.: "El principio de libertad de empresa", en Garrido Falla, F. (Dir. y Coord.): El modelo económico en la Constitución Española (I), Instituto de Estudios Económicos, 1981, págs. 158 y ss. 
se acaban de mencionar (libertad de competencia) ${ }^{30}$, en los que se va a centrar nuestra atención de modo más inmediato.

La mayor concienciación de los Estados, en torno a la necesidad de implicarse en la regulación del libre mercado, está relacionada con la concepción de una "economía social de mercado" que, decíamos, recoge nuestra Norma Suprema: ese calificativo "social" se traduce principalmente, a la hora de justificar tal incipiente tendencia al intervencionismo estatal, en que se viene a atribuir a la libertad de empresa una "función social", idéntica a la de la propiedad y a la de la herencia (art. 33.2 CE 1978), en el marco de una economía de mercado; o, en otras palabras, "se trata de encontrar un compromiso entre la libertad económica (o de empresa) y la igualdad social, sin renunciar a la intervención de los poderes públicos, para mantener el mercado y la competencia económica ${ }^{31}$, y para alcanzar las finalidades sociales cuando éstas resulten frustradas por el acontecer del mercado, compromiso que significa aunar la eficacia económica con la justicia social", tratando, en definitiva, de alcanzar la meta representada por la equiparación del "nivel", o, en términos más contemporáneos, de la "calidad" de vida de todos los españoles (recogida expresamente en el artículo 130.1 CE 1978, in fine) $)^{32}$.

El logro de un libre mercado regulado por el poder público tiene su reconocimiento supranacional en nuestro ámbito en el artículo 3 del llamado Tratado constitutivo de la Comunidad Económica Europea (TCEE, posterior TCE y actual Tratado de Funcionamiento de la Unión Europea o TFUE) que, entre las acciones a acometer por la misma, incluía “c) Un mercado interior caracterizado por la supresión, entre los Estados miembros, de los obstáculos a la libre circulación de mercancías, personas, servicios y capitales", así como "g) Un régimen que garantice que la competencia no será falseada en el mercado interior". Para el aseguramiento de la primera, esto es, la libre competencia, son establecidas una serie de reglas o normas "antitrust" 33 de naturaleza jurídico-pública (ad-

30 Consideró en su momento Broseta Pont que la competencia "presupone la existencia de tres requisitos: [...] En primer lugar, la libertad de iniciativa, o de acceso a la actividad económica. En segundo lugar, libertad para determinar las circunstancias y el modo, o forma de actividad (calidad, modelos, cantidad, producción, etc.). Finalmente, es esencial la igualdad de los competidores ante la Ley". En tanto alguno de estos "presupuestos constitutivos" fuera quebrantado, ha de negarse, en absoluto, la existencia de una libre competencia (Broseta Pont, M.: Manual de..., ob. cit., pág. 125).

31 Según se ha apuntado, "la relación entre libre competencia y mercado es evidente; en realidad, no puede hablarse de mercado donde no haya competencia, aunque sea limitada e imperfecta" (González Rus, J.J.: "Delitos contra el patrimonio y...(VIII)", ob. cit., 1996, pág. 769; anteriormente, González Rus, J.J.: Los intereses económicos de los consumidores. Protección penal, Instituto Nacional del Consumo, 1986, pág. 168). En realidad, y como se han encargado de constatar los economistas modernos, no puede hablarse en el capitalismo actual más que de una competencia imperfecta (también llamada "efectiva, practicable, operativa, suficientemente eficaz o "workable competition'”, Garrigues, J.: La defensa de la competencia mercantil, Sociedad de Estudios y publicaciones, 1964, pág. 29 y Galán Corona, E.: Acuerdos restrictivos de la competencia, Montecorvo, 1977, pág. 36), que requiere para su efectivo funcionamiento la concurrencia de una serie de requisitos mínimos: libertad de acceso al mercado; libertad de acción, es decir, libertad de determinación de las condiciones en que ha de tener efecto la organización y desenvolvimiento de la actividad económica en el mercado, lo que implica, en el lado de la oferta, libertad de los empresarios competidores de elección de la actividad, de los medios con que se elaboran los productos o median los servicios, de la forma y técnicas empleadas y, en el lado de la demanda, libertad de elección entre las distintas ofertas por parte de los consumidores y usuarios, especialmente; y, por último, igualdad de condición y oportunidades de todos los que acceden al mercado (Font Galán, J.I.: Constitución económica ..., ob. cit., págs.. 52 y ss., y Massaguer Fuentes, J.: Comentario a la Ley de Competencia Desleal, Civitas, 1999, págs. 110-111).

32 Rodríguez de Quiñones y de Torres, A.: "La protección del consumidor en...”, ob. cit., pág. 1.811.

33 Como apunta Cases Pallarés, el Derecho "antitrust" con origen en los Estados Unidos de América "ha tenido y tiene una notable influencia en el Derecho comunitario de la competencia" (Cases Pallarés, L1.: Derecho administrativo de la defensa de la competencia, Marcial Pons, 1995, pág. 57). 
ministrativa $)^{34}$ para su defensa por parte de las diferentes Administraciones ${ }^{35}$; no obstante, es preciso que ese cuerpo normativo sea complementado por la segunda de las acciones citadas, es decir, la implementación de un régimen jurídico-privado (mercantil) ${ }^{36}$ que permita que la competencia se desarrolle por medios correctos o leales, para evitar que "las decisiones de los operadores económicos y de los consumidores" se vean "viciadas por las actuaciones incorrectas que se produzcan en el mercado" y que podrían distorsionar "las decisiones de quienes participan en él"

\subsection{La libertad de empresa y la protección del consumidor}

En cuanto al segundo de los límites internos de la libertad de empresa, es decir, la protección a los consumidores se ha reconocido dentro de la propia doctrina mercantilista "que las normas reguladoras de la competencia mercantil ya no están exclusivamente orientadas a proteger o tutelar a los empresarios, sino que tienden también a defender los intereses de los consumidores, así como sus derechos económicos y sociales"38.

En este sentido, se ha afirmado que la importancia creciente de la tutela del consumidor, sobre todo a partir del mandato constitucional contenido en el artículo $51 \mathrm{CE}$ 1978, cobra sentido en tanto su figura se concibe como un "poder compensador en una economía de mercado, que debe equilibrarse con el principio de libertad de empresa consagrado en el artículo 38 de la Constitución" 39 , tal y como hemos visto.

34 Implementadas en España por la Ley 15/2007, de 3 de julio, "de Defensa de la Competencia" (LDC, reformada cinco veces, la última vigente a partir de 27 de mayo de 2017), tratándose de una ley que, tal y como recoge su Preámbulo, "parte de la experiencia adquirida en los últimos quince años mediante la aplicación de las normas nacionales y comunitarias de competencia y está guiada por cinco principios claros: garantía de la seguridad jurídica de los operadores económicos, independencia de la toma de decisiones, transparencia y responsabilidad frente a la sociedad de los órganos administrativos encargados de la aplicación de la Ley, eficacia en la lucha contra las conductas restrictivas de la competencia y búsqueda de la coherencia de todo el sistema y, en particular, de una adecuada imbricación de los distintos planos institucionales que interactúan en este terreno".

35 Soriano García, J.E.: Derecho público de la competencia, Marcial Pons, 1998, pág. 35.

36 La principal norma española en la materia es la Ley 3/1991, de 10 de enero, "de Competencia Desleal" (LCD, con hasta seis reformas, la última en vigor desde el 13 de marzo de 2019), ley que, según su propio Preámbulo, trataba de erigirse en su momento en "una Ley general, capaz de satisfacer la heterogénea demanda social que registra el sector desde la perspectiva unitaria del fenómeno concurrencial; una Ley moderna, inspirada en los modelos de regulación más avanzados y susceptible de situar a nuestro ordenamiento de la competencia en la órbita del Derecho europeo del momento; una Ley, en fin, de corte institucional, apta para garantizar o asegurar una ordenación del juego competitivo acorde con la escala de valores e intereses que ha cristalizado en nuestra constitución económica".

37 Bercovitz Rodríguez-Cano, A.: "Presentación", en Bercovitz Rodríguez-Cano, A. (Dir.): Derecho de la Competencia y Propiedad Industrial en la Unión Europea, Aranzadi, 2007, págs. 15-16. Sobre la existencia de unos intereses y un objeto de protección comunes entre la normativa "antitrust" y la normativa de competencia desleal, véase Molina Blázquez, C.: Protección jurídica de la lealtad en la competencia, Montecorvo, 1993, págs. 64-67.

38 Broseta Pont, M.: Manual de..., ob. cit., pág. 157.

39 Broseta Pont, M.: Manual de..., ob. cit., pág. 158. Sin embargo, creemos que esta "magnificación" de la figura del consumidor, tal y como hemos visto en el texto principal, no se corresponde con la realidad, esto es, con la visión actual del mismo como "sujeto manipulable". Sólo desde este último punto de vista puede justificarse la intervención del Derecho Penal en ámbitos tales como el que atañe a la publicidad engañosa, en orden a dos consideraciones o presupuestos básicos: primero, con el fin de asegurar el correcto funcionamiento del mercado, pues, siendo un elemento esencial del mismo, el consumidor se encuentra en una posición de inferioridad al actuar en su marco (lo que le impediría desenvolverse con total libertad) y, segundo, porque "su patrimonio puede verse directamente afectado por prácticas ilícitas o desleales" (De la Cuesta Aguado, P.M.: "Protección penal de los consumidores", en Revista General de Derecho, núm. 668, 2000, pág. 5.609). 
En efecto, el artículo 51 de la CE $1978^{40}$ establece lo siguiente:

"1. Los poderes públicos garantizarán la defensa de los consumidores y usuarios, protegiendo, mediante procedimientos eficaces, la seguridad, la salud y los legítimos intereses de los mismos".

El fundamento de esta "constitucionalización de la protección de los consumidores", aparte de guardar una innegable relación con las mencionadas acciones comunitarias (teniendo en cuenta las crecientes expectativas españolas en esa época por entrar a formar parte de la entonces CEE), deriva de una evolución en la concepción del consumidor que, configurado primeramente como "rey del mercado", como soberano en su libertad de elección ante los productos ofertados, en el marco de una tesis neocapitalista, aparece ahora, en el contexto del capitalismo avanzado, como un sujeto "manipulable". Esta nueva visión es la que justifica que el Estado intervenga para proporcionarle la protección que él no se puede procurar, frente a la "concentración empresarial y a las cada vez más penetrantes y agresivas técnicas de "marketing"'41, si empezamos a tomar en consideración la actividad publicitaria en esta ecuación de intereses sociales interrelacionados.

Una vez protegido por la Norma Suprema del ordenamiento español, fue el momento de que las distintas ramas del mismo, desde su especificidad, amparasen en su normativa al consumidor o, más concretamente, sus intereses, como objeto de protección. Así, en desarrollo del mandato constitucional del artículo 51 CE 1978 anteriormente transcrito, se creó la "Ley General para la Defensa de los Consumidores y Usuarios" (LGDCU), de 19 de julio de 1984, que allanó el camino al vigente Real Decreto Legislativo 1/2007, de 16 de noviembre, por el que se aprueba el Texto Refundido de la Ley General para la Defensa de los Consumidores y Usuarios y otras leyes complementarias $(\text { TRLGDCU) })^{42}$.

Esta protección a nivel nacional se enmarca dentro de la ofrecida por el ordenamiento comunitario europeo, que en el TFUE contiene muy diversas menciones (artículo 4, apartado 2, letra f) ${ }^{43}$; y artículos $12^{44}$ y $114^{45}$ ) a la protección de los consumidores, incluyendo

40 Para una interesante y exhaustiva exposición del trámite parlamentario seguido en la elaboración del precepto analizado por las Cortes Generales constituyentes, véase Rodríguez de Quiñones y de Torres, A.: "La protección del consumidor en...", ob. cit., págs. 1.790 y ss.

41 Rodríguez de Quiñones y de Torres, A.: "La protección del consumidor en...”, ob. cit., pág. 1.814.

42 El artículo 3 del TRLGDCU nos da un concepto de general de "consumidor" al que atenernos: "A efectos de esta norma y sin perjuicio de lo dispuesto expresamente en sus libros tercero y cuarto, son consumidores o usuarios las personas físicas que actúen con un propósito ajeno a su actividad comercial, empresarial, oficio o profesión. Son también consumidores a efectos de esta norma las personas jurídicas y las entidades sin personalidad jurídica que actúen sin ánimo de lucro en un ámbito ajeno a una actividad comercial o empresarial”. Doctrinalmente, Bourgoigne propone entender como consumidor "la persona física o jurídica que adquiere, posee o utiliza un bien o un servicio colocado en el sistema económico por un profesional sin perseguir ella misma la fabricación, transformación, distribución o prestación en el marco de un comercio o de una profesión" (Bourgoigne, T.: Elementos para una teoría del Derecho de Consumo (traducido por GABISER), Gobierno Vasco, 1994, pág. 47).

43 Artículo $4[\ldots]$ 2. Las competencias compartidas entre la Unión y los Estados miembros se aplicarán a los siguientes ámbitos principales: [...] f) la protección de los consumidores".

44 De conformidad con el artículo 12 del TFUE, al definirse y ejecutarse otras políticas y acciones de la Unión deben tenerse en cuenta las exigencias de la protección de los consumidores.

45 El artículo 114 del TFUE sirve de base jurídica a las medidas de armonización que tienen por objeto el establecimiento del mercado interior. Hace hincapié en el objetivo de garantizar un nivel de protección elevado, también en relación con la protección de los consumidores, y estar al día de las novedades basadas en hechos científicos. 
específicamente un Título XV con esa rúbrica (artículo 169) ${ }^{46}$, así como en el artículo 38 de la Carta de Derechos Fundamentales de la Unión Europea (CDFUE), el cual proclama que "En las políticas de la Unión se garantizará un nivel elevado de protección de los consumidores". Entre la muy diversa normativa derivada y sectorial (seguidamente haremos referencia a la estrictamente relacionada con la actividad publicitaria) actualmente en vigor, destacan por su importancia la Directiva 2011/83/UE del Parlamento Europeo y del Consejo, de 25 de octubre, sobre los derechos de los consumidores, así como el Reglamento (UE) 2017/2394 del Parlamento Europeo y del Consejo, de 12 de diciembre, sobre la cooperación entre las autoridades nacionales responsables de la aplicación de la legislación en materia de protección de los consumidores, el cual conecta a todas estas autoridades en una red europea y pone a su disposición un marco de intercambio de información y de cooperación para impedir que se infrinjan las leyes que regulan la protección de los consumidores (por ejemplo, sobre publicidad engañosa, viajes combinados o ventas a distancia).

\subsection{Libre (y leal) competencia, protección del consumidor y actividad publicitaria}

Pese a que se ha señalado que, en lo que se refiere concretamente al Derecho de la $\mathrm{Pu}-$ blicidad, "desde un punto de vista sistemático, la acción comunitaria se inscribe en el desarrollo de un ordenamiento europeo contra la competencia desleal" ${ }^{47}$ para contribuir al aseguramiento del correcto funcionamiento del sistema de libre competencia, no es menos cierto que el reconocimiento en el Derecho comunitario originario de la protección del consumidor ha dado lugar a que, a la hora de regular la actividad publicitaria en el ámbito de la UE, se desarrolle también una normativa derivada específica, en la que también los intereses (principalmente económicos) de los consumidores (y no sólo ya los de los oferentes), se vean resguardados frente a aquélla; así, por ejemplo, y en lo que nos interesa, fue esencial en su momento la Directiva 84/450/CEE, de 10 de septiembre, para la armonización de las disposiciones legislativas, reglamentarias y administrativas de los países miembros sobre publicidad engañosa.

De acuerdo con la voluntad de la susodicha Directiva 84/450/CEE sobre publicidad engañosa, llegó, tras el precedente del Estatuto de Publicidad de 19648, la Ley 34/1988,

46 El artículo 169 del TFUE establece una base jurídica para toda una serie de acciones a escala de la Unión en el ámbito de la protección de los consumidores. En él se prevé que «para promover los intereses de los consumidores y garantizarles un alto nivel de protección, la Unión contribuirá a proteger la salud, la seguridad y los intereses económicos de los consumidores, así como a promover su derecho a la información, a la educación y a organizarse para salvaguardar sus intereses». También se contempla un refuerzo de la atención a los intereses de los consumidores en otras políticas de la Unión. En este sentido, el artículo 169 del TFUE refuerza lo dispuesto en el artículo 114 y amplía su ámbito de aplicación más allá de los aspectos del mercado único para incluir el acceso a bienes y servicios, el acceso a los tribunales, la calidad de los servicios públicos y cuestiones relacionadas con la nutrición, la alimentación, la vivienda y la política sanitaria. El artículo dispone, además, que las medidas que adopte la Unión no deben impedir que cada uno de los Estados miembros mantenga y adopte medidas de mayor protección, siempre que sean compatibles con los Tratados. Por consiguiente, la política de los consumidores forma parte del objetivo estratégico de la Unión de mejorar la calidad de vida de sus ciudadanos. Además de las medidas directas orientadas a proteger sus derechos, la Unión vela por la integración de los intereses de los consumidores en su legislación relativa a todos los ámbitos de actuación pertinentes.

47 Soler Masota, P., "Panorama del Derecho de la Publicidad...", ob. cit., pág. 359. Probablemente se limita la autora a dar esta visión unidimensional por encontrarse bajo el influjo propio de la doctrina mercantilista, la cual ha considerado tradicionalmente la publicidad como "un elemento imprescindible para que se pueda desarrollar la competencia en el mercado" (Broseta Pont, M.: Manual de..., ob. cit., pág. 155).

48 Aprobado por Ley 61/1964, de 11 de junio. Hay autores que subrayan que éste únicamente ofrecía protección a los profesionales del sector (Cugat Mauri, M.: "La protección de los intereses colectivos: el caso del delito 
de 14 de diciembre, "General de Publicidad" (LGP), con fundamento en "la inadecuación de la legislación entonces vigente en esta materia" ${ }^{49}$. Los contenidos vigentes de esta última norma vienen actualmente perfilados por la Ley 29/2009, de 30 de diciembre, por la que se modifica el régimen legal de la competencia desleal y de la publicidad para la mejora de la protección de los consumidores y usuarios, sobre la base de dos nuevas normas comunitarias: la Directiva 2005/29/CE del Parlamento Europeo y del Consejo, de 11 de mayo, relativa a las prácticas comerciales desleales de las empresas en sus relaciones con los consumidores en el mercado interior (que modificaba, entre otras, a la mencionada Directiva 84/450/CEE) y la Directiva 2006/114/CE del Parlamento Europeo y del Consejo, de 12 de diciembre, sobre publicidad engañosa y publicidad comparativa (que vino a codificar, precisamente, las modificaciones de la tan mencionada Directiva 84/450/CE).

\subsection{Conclusión: el delito de publicidad engañosa como delito económico relativo al mercado y a los consumidores}

Impulsado sin duda por la voluntad de tutelar todos y cada uno de los intereses sociales que se acaban de exponer, el legislador penal español decidió contemplar tres grupos de infracciones en el Capítulo XI del CP $1995^{50}$ bajo la rúbrica "Delitos relativos a la propiedad intelectual e industrial, al mercado y a los consumidores": A) Los delitos que afectan a la capacidad competitiva de la empresa, entre los que se encuentran los delitos relativos a la propiedad intelectual (Sección 1a, arts. 270 a 272), propiedad industrial (Sección 2a, arts. 273 a 277), más los ya pertenecientes a la "heterogénea" Sección $3^{\text {a51 }}$ : descubrimiento y revelación de secretos de empresa (arts. 278 a 280) y uso indebido de información privilegiada (arts. 285 y 285 bis), a los que habría que añadir los postreros delitos de facilitación o suministro de acceso a servicios de radiodifusión o interactivos (art. 286); B) Los delitos que atentan a los intereses de los consumidores ${ }^{52}$, entre los que hay que destacar el delito de publicidad engañosa (art. 282), el más reciente delito de falsedad en las informaciones

publicitario", en Quintero Olivares, G. y Morales Prats, F. (Coords.): El nuevo Derecho Penal Español. Estudios Penales en Memoria del profesor José Manuel Valle Muñiz, Aranzadi, 2001, nota 5, pág. 1168).

49 Muñagorri Laguía, I.: La protección penal de los consumidores frente a la publicidad engañosa (Art. 282 del Código Penal), Comares, 1998, pág. 18.

50 Miró Llinares, F.: La protección penal de la propiedad intelectual..., ob. cit., pág. 248.

51 El contenido de la Sección Tercera de este Capítulo XI viene a estructurarse cual "microrreflejo" de éste. Así, respectivamente, encontramos tres grupos de figuras de carácter "heterogéneo" (Moreno y Bravo, E.: "Delitos relativos al mercado y a los consumidores", en Bacigalupo Zapater, E. (Dir.): Curso de Derecho Penal Económico, Marcial Pons, 1998, pág. 279. El mismo adjetivo utiliza Valle Muñiz, J.M.: “Artículo 282”, en Quintero Olivares, G. (Dir.): Comentarios al Nuevo Código Penal, Aranzadi, 1996 (1ª edición), pág. 1.256): A) El descubrimiento y revelación de secretos de empresas (arts. 278, 279 y 280), en los que se viene a tutelar directamente la capacidad competitiva de la empresa, como hemos señalado en el texto principal, junto al "insider trading" (arts. 285 y 285 bis) y el denominado coloquialmente "delito Polanco" (art. 286); B) Delitos dirigidos estrictamente contra los consumidores: nuestro artículo 282, que ha sido calificado como "el injusto más arquetípico de los delitos socioeconómicos relativos a los consumidores" (Moreno y Bravo, E.: "Delitos relativos al mercado y...", $o b$. cit., pág. 293) y el 283, que protegen los intereses económicos de los mismos como colectivo, en relación, respectivamente, a la publicidad (más el art. 282 bis) y suministro de determinados productos; C) Delitos contra el mercado (arts. 281, 284 y 286 bis, ter y quater), en los que se contemplan una serie de aspectos necesarios para el correcto funcionamiento del mismo.

52 Relacionando la tipificación de estos delitos con el modelo económico constitucionalmente consagrado, Torío López apuntó que el injusto de los delitos contra los consumidores es una acción discrepante del modelo económico fundamental plasmado en la Constitución; menoscaba, pues, el interés colectivo en el orden del modelo de economía (social) de mercado (Torío López, Á.: "Reflexión sobre la protección penal de los consumidores", en AAVV: Estudios sobre el Derecho de consumo, Fundación Iberdrola, 1991 (1ª edición), págs. 105 y 112). 
suministradas en el mercado de valores (art. 282 bis) y el de facturación falsa (art. 283); y C) Los delitos contra el libre mercado, como son los delitos de detracción de materias primas o productos de primera necesidad (art. 281), los delitos de alteración de los precios derivados de la libre competencia (art. 284), así como los más recientes delitos de corrupción en los negocios de la Sección $4^{\text {a }}$ (arts. 286 bis, ter y quater).

Se puede observar cómo este Capítulo XI, dentro del Título XIII ("Delitos contra el patrimonio y contra el orden socioeconómico"), viene a responder a una necesidad de protección de, en términos generales, el sistema de libre competencia con todos sus elementos e intereses sociales implicados ${ }^{53}$, como idea que, a un nivel más concreto, permite justificar que la actividad publicitaria de carácter engañoso venga tipificada en el artículo 282 del CP 1995, calificado en lógica consonancia como "delito económico" 54 .

Es conveniente resaltar que, pese a regularlos conjuntamente, el CP 1995 no ofrece ni siquiera criterios para la diferenciación entre "delitos patrimoniales" y "delitos económicos o socioeconómicos", a pesar de que la misma sería importante a efectos de determinar, por ejemplo, la existencia de un concurso de leyes o de delitos en caso de concurrir en la conducta de un mismo sujeto ${ }^{55}$; por ello, la doctrina ha tratado de suplir el trabajo que correspondería propiamente al legislador ${ }^{56}$. En todo caso, de lo que no cabe duda es que la incorporación al Código de un Título dedicado específicamente a los delitos económicos "ha sido una demanda doctrinal prácticamente unánime y largamente sostenida" ${ }^{57}$, si bien ahora se ve sólo "satisfecha parcialmente, en la medida en que se mantiene la unidad de tratamiento con los patrimoniales" 58 .

Así, pues, es necesario, para llegar a aprehender en sus justos términos lo que esta calificación supone, realizar una breve exposición sobre qué entiende la doctrina por "delito económico".

53 Miró Llinares, F.: La protección penal de la propiedad intelectual..., ob. cit., pág. 247, pues mediante tal protección se logra que el capital privado se someta al orden público económico, "en beneficio de la economía nacional y de los consumidores" (Broseta Pont, M.: Manual de..., ob. cit., pág. 126).

54 Por todos, Valle Muñiz, J.M.: "Artículo 282", ob. cit., pág. 1.277, y Carrasco Andrino, M.M.: La publicidad engañosa y el Derecho Penal (una aproximación al tipo del artículo 282 del C.P.), Revista General de Derecho, 2000, pág. 83.

55 Así lo apunta González Rus, J.J.: "Delitos contra el patrimonio y contra el orden socioeconómico (I)”, en Cobo del Rosal, M. (Dir.): Compendio de Derecho penal español (Parte Especial), Marcial Pons, 2000, pág. 375.

56 En este sentido, González Rus interpreta que, "en realidad, ni el propio Código cree que la diferenciación sea innecesaria, pues sistemáticamente la línea fronteriza entre unos y otros delitos la sitúa en las disposiciones comunes del Capítulo X, en cuyo artículo 268 parece calificar de 'delitos patrimoniales' a los recogidos en los anteriores" (González Rus, J.J.: "Delitos contra el patrimonio y... (I)”, ob. cit., 2000, pág. 375). Sería de esta misma opinión Martínez - Buján Pérez, que entiende, según recoge Miró Llinares, que es posible distinguir dos bloques de delitos dentro del Título XIII: los patrimoniales en sentido propio (Capítulos I a IX) y los socioeconómicos (Capítulos XI a XIV, exceptuando la receptación) sobre la base de que, entre ambos, se intercala ese Capítulo X al que se refería González Rus. Sin embargo, el propio Miró Llinares, siguiendo los razonamientos de Del Rosal Blasco en su trabajo sobre Los delitos societarios en el Código Penal de 1995 (Tirant lo Blanch, 1998), sobre la base de los cuales interpretar el artículo 268 como "bisagra separadora" entre ambos bloques excedería más allá de lo admisible (si bien admite este último autor que "a lo sumo, lo que de dicho texto se podría extraer es que para el legislador de 1995 los delitos de los capítulos anteriores al capítulo X del título XIII son de naturaleza patrimonial, pero ello no prejuzga la naturaleza de los delitos recogidos en los capítulos ulteriores, que podrá ser patrimonial o socioeconómica"), añade que tampoco estaba en el ánimo de quienes participaron en los debates parlamentarios previos a la aprobación del CP 1995 abordar dicha distinción (y lo hace sobre la base del trabajo de los profesores López Garrido, D. y García Arán, M.: El Código Penal de 1995 y la voluntad del legislador, Eurojuris, 1996, pág. 128), entendiendo, por tanto, que "no hay, en el Código Penal de 1995, una separación tajante entre delitos patrimoniales y económicos" (Miró Llinares, F.: La protección penal de la propiedad intelectual..., ob. cit., págs. 246-247).

57 González Rus, J.J.: "Delitos contra el patrimonio y... (I)”, ob. cit., 2000, pág. 378.

58 González Rus, J.J.: "Delitos contra el patrimonio y... (I)”, ob. cit., 2000, pág. 378. 
Desde una concepción del Derecho Penal Económico en sentido estricto, se formula una definición del delito económico como "la infracción jurídico-penal que lesiona o pone en peligro el orden económico entendido como regulación jurídica del intervencionismo estatal en la Economía de un país" ${ }^{\prime 59}$. No obstante, Bajo y Bacigalupo son conscientes de que esta definición no abarcaría determinados rasgos criminológicos, lo cual hace necesaria una ampliación de este concepto. De hecho, hay autores que, como Pérez del Valle, desde una perspectiva en la que el bien jurídico (como objeto de protección de la norma penal) se relativiza, definen los delitos económicos como "aquellos comportamientos descritos en las leyes que lesionan la confianza en el orden económico vigente con carácter general o en alguna de sus instituciones en particular y, por tanto, ponen en peligro la propia existencia y las formas de actividad de ese orden económico", partiendo de una concepción teleológico-subjetiva del Derecho Penal Económico en sentido estricto como el "dedicado al estudio de estos delitos y de las consecuencias jurídicas que las leyes prevén para sus autores" ${ }^{" 60}$.

Bajo Fernández y Bacigalupo Saggese ofrecen, pues, una nueva definición de delito económico, desde una concepción del Derecho Penal Económico en sentido amplio, como "aquella infracción que, afectando a un bien jurídico patrimonial individual, lesiona o pone en peligro, en segundo término, la regulación jurídica de la producción, distribución y consumo de bienes y servicios" 61 .

En cuanto al reflejo que tales definiciones dogmáticas han tenido en el ordenamiento penal positivo, se apunta que, tanto el PLOCP 1980 como el APNCP 1983 siguieron esta concepción amplia del delito económico ${ }^{62}$, y que, igualmente, el orden socioeconómico contemplado en el Título XIII CP 1995 no es, según González Rus, el estricto, sino que aparece contemplado en "su sentido más genérico. De hecho - añade el autor - no se ha utilizado la expresión delitos económicos, sino la de delitos socioeconómicos, de significación más imprecisa"63. En cambio, creemos que podemos hablar del tipo penal de publicidad engañosa del art. 282 CP 1995 "como un auténtico tipo contra el orden socioeconómico o delito económico sensu stricto" elección económica los consumidores como colectivo.

En efecto, no es discutible que, como hemos visto al comienzo de este trabajo, a la actividad publicitaria se le han venido atribuyendo ciertos efectos macroeconómicos, entre los cuales se ha señalado, efectivamente, la potenciación o inhibición de la competitividad $^{65} \mathrm{o}$, también, relacionándola con esa función social del modelo económico que la Constitución consagra, la contribución al bienestar económico ${ }^{66}$.

59 Bajo Fernández, M. y Bacigalupo Saggese, S.: Derecho penal económico, ob. cit., pág. 14.

60 Pérez del Valle, C.: “Introducción al Derecho Penal Económico”, en Bacigalupo Zapater, E. (Dir.): Curso de ... ob. cit., pág. 23.

61 Bajo Fernández, M. y Bacigalupo Saggese, S.: Derecho penal económico, ob. cit., pág. 15.

62 Bajo Fernández, M. y Bacigalupo Saggese, S.: Derecho penal económico, ob. cit., nota 20, pág. 16.

63 González Rus, J.J.: "Delitos contra el patrimonio y... (I)", ob. cit., 2000, pág. 378.

64 Moreno y Bravo, E.: "Delitos relativos al mercado y...", ob. cit., pág. 294.

65 León, J.L.: Los efectos de la publicidad, Ariel Comunicación, 1996, págs. 161 y ss. El autor rehúye adoptar una toma de posición al respecto, pues afirma que "[...] no puede plantearse de modo absoluto el dilema de si la publicidad es pro o anti competitiva, pues es obvio que paradójicamente puede servir a ambos fines dependiendo de cómo sea utilizada [...]" (León, J.L.: Los efectos de... ob. cit., pág. 165). Carrasco Andrino sí se posiciona al respecto, al afirmar que la publicidad "[...] intensifica la competencia, reduciendo los precios, ya que el consumidor dispone de una mayor y más rápida información de los distintos productos ofertados en el mercado" (Carrasco Andrino, $\mathrm{M}^{\mathrm{a}}$.M.: La publicidad engañosa y el Derecho Penal..., ob. cit., pág. 16).

66 Si es que se parte de una concepción de la publicidad como instrumento de política económica mediante el cual sea posible elevar el volumen de consumo general de un país. Exponiendo argumentos a favor y en contra de esta 
Fue de algún modo el ordenamiento comunitario europeo el primero en advertir esta interacción entre publicidad y competencia y, así, para el logro de uno de sus más tradicionales objetivos, sus acciones en materia de Derecho de la publicidad se inscriben en el desarrollo de un ordenamiento europeo contra la competencia desleal ${ }^{67}$, principalmente "como instrumento necesario para la consecución de un mercado interior plenamente integrado [...]"68, tal y como hemos visto en los apartados anteriores. Es decir, la regulación del Derecho comunitario europeo sobre la publicidad, que anteriormente hemos referido, busca asegurarse de que los sujetos oferentes "jueguen limpio" a la hora de ofrecer sus productos a los consumidores, pero, paralelamente, la protección que para éstos emana de aquella regulación "no debe constituir un fin en sí misma, sino tan sólo un presupuesto o condición previa para lograr mercados transparentes" $" 69$ que, se sobreentiende, reviertan, en último término, en un beneficio para los propios consumidores.

Ese "beneficio" se concretaría en que el hecho de que la presencia de un "número suficiente" de empresas viene a garantizar la libertad de elección (económica) de los consumidores entre las diferentes opciones que se le presentan, de modo que aquéllas se vean "obligadas a mejorar su posición en el mercado, lo que produce beneficiosos efectos en la calidad, pluralidad, oferta, presentación, distribución y precio de los artículos"70. Es en este punto donde surge la necesidad de lograr "mercados transparentes" en los que la competencia únicamente produzca efectos beneficiosos para los consumidores y, por ende, éstos refuercen su confianza en el sistema de mercado de modo que, finalmente, la Economía del país crezca cuantitativa y cualitativamente.

\section{CONTENIDO DEL BIEN JURÍDICO-PENAL PROTEGIDO EN EL ARTÍCULO 282 CP 1995}

Estas disquisiciones ya nos llevan irremediablemente a elaborar lo que pretende ser una exposición descriptiva sobre el contenido del bien jurídico-penal protegido en el artículo 282 CP 1995. Así, intentaremos acometer desde este momento, ordenada y sistemáticamente, una labor recopiladora de algunas de las más autorizadas opiniones doctrinales en torno a esta cuestión desde la misma promulgación de este delito a finales del siglo pasado.

La doctrina ha sido casi unánime a la hora de definir el contenido material del bien jurídico-penal protegido en el delito de publicidad engañosa haciendo alusión a: $1^{\circ}$ ) los intereses sociales y, sobre todo, económicos, de los consumidores, concretados específicamente en $2^{\circ}$ ) el derecho de éstos a una información veraz en la actividad publicitaria (en tanto destinatarios de la misma), como requisito fundamental $3^{\circ}$ ) para asegurar su libertad de elección dentro del mercado ${ }^{71}$, sin interferencias de fraudes publicitarios, en la adqui-

posible función de la publicidad, León, J.L.: Los efectos de... ob. cit., págs. 174 y ss.

67 Véase Soler Masota, P.: "Panorama del Derecho de la Publicidad...", ob. cit., pág. 359.

68 Soler Masota, P.: "Panorama del Derecho de la Publicidad...", ob. cit., pág. 359.

69 Soler Masota, P.: "Panorama del Derecho de la Publicidad...", ob. cit., pág. 361; lo cual constituye "uno de los ideales de la competencia perfecta" (Carrasco Andrino, Ma.M.: La publicidad engañosa y el Derecho Penal..., ob. cit., pág. 22).

70 González Rus, J.J.: “Delitos contra el patrimonio y...(VIII)”, ob. cit., 1996, pág. 768.

71 Martínez Pérez, C.: "El delito de publicidad engañosa en el Anteproyecto de Código Penal español de 1992", en AAVV: Hacia un derecho penal económico europeo. Jornadas en honor del profesor Klaus Tiedemann, Boletín Oficial del Estado, 1995, pág. 236. 
sición o rechazo de los productos y servicios ofertados, facilitándoles un conocimiento adecuado sobre el uso, consumo y disfrute de los mismos.

Es decir, siguiendo a Martínez Pérez, "el bien tutelado se articula sobre la base del principio de veracidad publicitaria y se concreta en la libertad de disposición económica del que demanda una mercancía o un servicio, o sea, el derecho que en las relaciones del mercado tienen los consumidores de decidirse con entera libertad en la adquisición o rechazo de un producto o servicio"72. Asegurando el ejercicio correcto de esta libertad, según Lampe, se obtendrá la necesaria "racionalidad económica" en el mercado, sin la cual no es posible garantizar la libre competencia ${ }^{73}$. Sobre la base de todo ello creemos que, como Miró Llinares afirma con respecto a los delitos relativos a la propiedad intelectual, en la incriminación de la conducta publicitaria engañosa influyen consideraciones de prevención general relacionadas con la política económica ${ }^{74}$ : el aseguramiento del derecho de los consumidores a una información publicitaria veraz busca proporcionarles un ámbito de libertad "absoluta" (sin interferencias) de elección, ante el cual, no quede a las empresas otra opción que ofrecer la mejor relación calidad - precio para que sean sus productos los elegidos (se cumpliría así la función social de incentivación de la competencia).

El referente material de tal derecho de los consumidores a recibir una información veraz en la actividad publicitaria se ha encontrado, lógicamente, en el ya analizado artículo 51 CE 1978, y, más controvertidamente, en el artículo 20.1.d) CE 1978, que consagra el derecho fundamental a "recibir libremente información veraz por cualquier medio de difusión"75.

72 Obsérvense los distintos niveles de progresiva concreción que hemos señalado ordinalmente en la definición, la cual ha sido elaborada a partir de los matices aportados en sus respectivas formulaciones, entre otros, por Bajo Fernández, M. y Bacigalupo Saggese, S.: Derecho penal económico, ob. cit., pág. 544; González Rus, J.J.: "Delitos contra el patrimonio y...(VIII)", ob. cit., 1996, pág. 768; Moreno y Bravo, E.: El delito de publicidad falsa. El artículo 282 del CP 1995, la protección penal de los consumidores frente a la actividad publicitaria falaz, Bosch, 2001, pág. 15; Muñagorri Laguía, I.: La protección penal..., ob. cit., págs. 71 y ss.; Macías Espejo, B.: El delito de publicidad engañosa, Dykinson, 2016, págs. 80-102; Choclán Montalvo, J.A.: "El delito publicitario en el nuevo Código Penal", en Actualidad Jurídica Aranzadi, núm. 256, 1996, pág. 2; Tamarit Sumalla, J.Ma.: "La tutela penal de los intereses de los consumidores en la actividad publicitaria: problemas fundamentales", en Cuadernos de Politica Criminal, núm. 41, 1990, págs. 333-334; Hernández Plasencia, J.U.: "El delito publicitario", en Actualidad Penal, núm. 48, 1997, pág. 1.103 y ss.; Rubio Lara, P.Á.: Parte Especial del Derecho penal económico (una aproximación al estado de la cuestión en la doctrina y jurisprudencia españolas), Dykinson, 2006, págs. 9293; Demetrio Crespo, E.: "A propósito del bien jurídico en el delito publicitario tipificado en el art. 282 del Código Penal español (una contribución a partir de una 'hermenéutica valorativa')", en Revista de Derecho y Proceso Penal, núm. 12, 2004, pág. 212; Portero Henares, M.: El delito publicitario en el Código Penal español, Tirant lo Blanch, 2004, págs.. 237-249; Santaella López, M.: Derecho de la publicidad, Civitas, 2003 (1ª edición), págs. 202-203. En definitiva, se trata de asegurar la libre formación de la voluntad del consumidor en lo que se refiere, específicamente, a la adquisición de bienes o servicios ofertados en el mercado (Bajo Fernández, M. y Bacigalupo Saggese, S.: Derecho penal económico, ob. cit., pág. 544 - 545), o, lo que es lo mismo, de garantizar "la libertad de disposición económica de los consumidores" (Valle Muñiz, J.M.: “Artículo 282", ob. cit., pág. 1.279). El Tribunal Constitucional también se ha encargado de definir el derecho a la información como el derecho del consumidor "a disponer de una información veraz y completa sobre las características esenciales del bien o servicio, de su calidad, composición, precio, etc., que le permitan dirigir la elección, utilizar el bien o servicio o reclamar la reparación de los eventuales daños causados por el producto adquirido o servicio utilizado" (STC 71/1982, citada en Rodríguez de Quiñones y de Torres, A.: "La protección del consumidor en...”, ob. cit., pág. 1.832).

73 Lampe, E.J.: "La protección jurídico-penal de la competencia económica en el Anteproyecto del Código Penal español de 1983", en Barbero Santos, M. (Ed.): Los delitos socio-económicos, Universidad Complutense de Madrid, 1985, pág. 384.

74 Miró Llinares, F.: La protección penal de la propiedad intelectual..., ob. cit., pág. 254.

75 Bajo Fernández, M. y Bacigalupo Saggese, S.: Derecho penal económico, ob. cit., pág. 542. En similar sentido, Sierra López, Ma․V.: Análisis jurídico-penal de la publicidad engañosa en Internet, Tirant lo Blanch, 2003, págs. 112 y ss. 
Decimos "controvertidamente" porque hay quien fundamenta su posición en contra de establecer esta última conexión, alegando que no cabe en el tipo la protección de la veracidad más que en el ámbito de las relaciones comerciales, "lo cual erradica del ámbito de protección de esta norma los aspectos de la información reconducibles al ejercicio de expresión o de prensa", justificándose en que "la exigencia de veracidad en la publicidad no puede encontrar soporte jurídico en el derecho a recibir comunicación veraz por cualquier medio de difusión del artículo 20.1. d) CE 1978, [...] pues un derecho individual difícilmente puede servir de soporte a un bien jurídico de carácter colectivo [...]" ${ }^{\text {76 }}$. Además, reforzando esta posición, se afirma que "situar la actividad publicitaria en la órbita del art. 20.1. d) CE hubiera exigido la aprobación de la Ley General de Publicidad bajo la forma de ley orgánica, ya que supondría el desarrollo de uno de los aspectos del derecho fundamental a la libertad de expresión o información (art. 81.2 CE)"'77.

A la hora de estudiar, en su literalidad, el bien jurídico-penal enunciado, destaca la imprecisión que el término "veracidad" encierra, lo cual ha llevado a los autores a preguntarse cuál ha de ser su concreto contenido. Partimos del hecho de que, además de ser un derecho de los consumidores, "el deber de veracidad sobre las características del producto goza de respaldo legal"78. Intentar ir más allá y adentrarse en conceptos de tal vaguedad e imprecisión como el que se nos presenta, excede de lo que nos es exigible en el presente trabajo; eso sí, no cabe duda de que, por evidentes razones de seguridad jurídica, ha de rechazarse de plano que la protección de la veracidad "en abstracto" y, consecuentemente, es necesario determinar las características que debe reunir como objeto de tutela penal ${ }^{79}$, tarea que será conveniente acometer por el operador jurídico de que se trate a la hora de analizar conceptos que, acompañados de otros elementos gramaticales, permitan una mayor concreción al respecto. Por todo ello, creemos que, la protección que el tipo de publicidad engañosa ofrezca a la veracidad en la información comercial, vendrá determinada por la falsedad del caso concreto, cuestión que habría que abordar en un análisis dogmático de la conducta típica para el que no tenemos espacio en este trabajo.

Dada la anterior definición del bien jurídico-penal protegido en el delito de publicidad engañosa, no ofrece dudas tampoco el carácter colectivo, supraindividual o "universal" 80 del mismo. Pero las matizaciones doctrinales surgen cuando los autores intentan profundizar un poco más en la caracterización de tal valor protegido. Así las cosas, Bajo Fernández y Bacigalupo Saggese apuntan que, de un modo indirecto, con la conducta tipificada en el artículo 282 CP 1995 "se está afectando también, sin lugar

76 Cugat Mauri, M.: "La protección de los intereses colectivos: el caso...”, ob. cit., págs. 1.173 - 1.179.

77 Carrasco Andrino, Ma.M.: La publicidad engañosa y el Derecho Penal..., ob. cit., pág. 79.

78 Así lo subrayaba Valle Muñiz sobre la base del derogado artículo 13 de la LGDCU, conforme al cual "Los bienes, productos y, en su caso, los servicios puestos a disposición de los consumidores y usuarios deberán incorporar, llevar consigo o permitir de forma cierta y objetiva una información veraz, eficaz y suficiente sobre sus características esenciales [...]" (Valle Muñiz, J.M.: “Artículo 282”, ob. cit., pág. 1.280). En la actualidad, las menciones que el TRLGDCU dedica al deber de ofrecer una información veraz a los consumidores se encuentran recogidas en los arts. 18 (etiquetado y presentación de los bienes y servicios), 20 (información necesaria en la oferta comercial de bienes y servicios) y 60 (información previa al contrato).

79 Cugat Mauri, M.: "La protección de los intereses colectivos: el caso...”, ob. cit., pág. 1.173.

80 Muñoz Conde, F.: Derecho Penal. Parte Especial, Tirant lo Blanch, 1996 (11 a edición), pág. 442. Esta adjetivación del bien jurídico (llamado también "bien común") es criticada desde algún sector de la doctrina alemana, como recoge Hefendehl, R.: “¿Debe ocuparse el Derecho Penal de riesgos futuros? Bienes jurídicos colectivos y delitos de peligro abstracto" (traducido por Eduardo Salazar Ortuño), en Revista Electrónica de Ciencia Penal y Criminología, núm. 4, 2002, nota 11, pág. 4. 
a duda, la libre competencia en la medida en que a través de la publicidad se accede al consumidor y éste juega un importante papel en la determinación de la oferta y la demanda" 81 , afirmación que es acorde con la idea de que en el Capítulo XI del Título XIII late la noción de competencia (de ahí, en nuestra opinión, la rotunda expresión empleada por los autores: "sin lugar a duda"). Pero añaden Bajo Fernández y Bacigalupo Saggese que se está afectando, además, “a bienes jurídicos individuales como el patrimonio" 82 , si bien afirman, seguidamente, que, a pesar de guardar cierta similitud con la conducta típica en la estafa, "nos encontramos aquí ante un bien jurídico fundamentalmente colectivo y supraindividual, cuya titularidad recae en los consumidores, adelantándose de esta forma la protección penal a un estadio en el que, como afirma Muñoz Conde, aún no se ha producido un daño patrimonial individual, pero se lesionan las expectativas del conjunto de consumidores" $"$.

Se ha llegado a afirmar en este sentido que una lesión del bien jurídico-penal protegido en el tipo del artículo 282 (el interés de los consumidores en la veracidad de la actividad publicitaria), supondría "un peligro para su patrimonio" 84 (que se podría calificar como un interés económico tangible); por ello mismo, hay quien defiende que nos encontramos ante un delito de peligro abstracto ${ }^{85}$ o hipotético ${ }^{86}$. En desarrollo de esta línea argumental, pero alejando el tipo penal del art. 282 de la estricta referencia al patrimonio, Terradillos Basoco considera que el interés difuso o colectivo de los consumidores en la veracidad de los medios publicitarios viene a ser contemplado en el CP únicamente "en la medida en que vaya referido, de modo más o menos inmediato, a bienes jurídicos individuales o individualizables" $"$. En opinión del autor, el CP viene a incriminar en este delito la creación de un peligro, producido a través de la lesión a una situación instrumental; o lo que es lo mismo, "la conducta típica lesiona el interés de los consumidores en la veracidad de la información publicitaria (configurada, por tanto, como bien jurídico intermedio ${ }^{88}$ ), pero esa lesión sólo pasa a ser típica cuando, a su vez, constituye un medio objetivamente idóneo para afectar a otros bienes jurídicos" ${ }^{99}$ que, en este caso, vendrían representados en concre-

81 Bajo Fernández, M. y Bacigalupo Saggese, S.: Derecho penal económico, ob. cit., pág. 545. De la misma opinión es Valle Muñiz, pues afirma que "[...] el bien jurídico se configura en torno al concepto de veracidad de la información, relegando a otros intereses tutelados, como las reglas de la libre competencia, a meros efectos mediatos de la protección penal" (Valle Muñiz, J.M.: "Artículo 282", ob. cit., pág. 1.279).

82 Bajo Fernández, M. y Bacigalupo Saggese, S.: Derecho penal económico, ob. cit., pág. 545.

83 Bajo Fernández, M. y Bacigalupo Saggese, S.: Derecho penal económico, ob. cit., pág. 545, citando a Muñoz Conde, F.: Derecho Penal, ob. cit., pág. 443.

84 González Rus, J.J.: "Delitos contra el patrimonio y...(VIII)", ob. cit., 1996, pág. 808.

85 Moreno y Bravo, E.: "Delitos relativos al mercado y...", ob. cit., pág. 294.

86 Valle Muñiz, J.M.: “Artículo 282”, ob. cit., pág. 1.281. Muñoz Conde, F.: Derecho Penal, ob. cit., pág. 444.

87 Terradillos Basoco, J.Ma .: "El delito de publicidad engañosa", en Ruiz Rodríguez, L.R. (Ed.): Sistema penal de protección del mercado y de los consumidores. Actas del II Seminario Internacional de Derecho Penal Económico (Jerez, diciembre 2000), Tirant lo Blanch, 2002, pág. 74.

88 En el sentido propuesto en Terradillos Basoco, J.M .: "Peligro abstracto y garantías penales", en Quintero Olivares, G. y Morales Prats, F. (Coords.): El nuevo Derecho Penal Español. Estudios Penales en Memoria del profesor José Manuel Valle Muñiz, Aranzadi, 2001, págs. 809 y ss. Es lo que otros autores denominan "bien jurídico 'espiritualizado' o 'institucionalizado' de índole colectiva, de la misma naturaleza dogmática que la seguridad del tráfico, la seguridad colectiva o la salud pública" (Moreno y Bravo, E.: "Delitos relativos al mercado...", ob. cit., nota 3, pág. 279). Véase, más genéricamente, Mata y Martín, R.M.: Bienes jurídicos intermedios y delitos de peligro, Comares, 1997.

89 Terradillos Basoco, J.Mª: "El delito de publicidad engañosa”, en Ruiz Rodríguez, L.R. (Ed.): Sistema penal de protección del mercado y... ob. cit., pág. 74 . 
to, y fundamentalmente, por el patrimonio ${ }^{90}$. Pese a lo expuesto, viene a aclarar Terradillos Basoco a lo largo de su exposición que, "aunque lo patrimonial delimite el objeto jurídico de protección, hay que observar que no contempla el artículo 282 los diferentes patrimonios individuales afectables de forma autónoma o aislada [...]. El consumidor individual, aunque pueda ser perjudicado civil, no es el sujeto pasivo, en cuanto no es titular del bien jurídico protegido, pues éste corresponde a una colectividad difusa" ${ }^{\prime 1}$.

\section{CONSIDERACIONES FINALES}

Pese a que la doctrina mayoritaria acogió satisfactoriamente la tipificación del delito de publicidad engañosa en el CP 1995, autorizadas voces dentro de la misma ya dudaban acerca de la conveniencia de la intervención penal ${ }^{92}$. Resolvamos, en primer lugar, en que la actividad publicitaria engañosa, de no haber sido tipificada expresamente, podría constituir simplemente, considerando en sí misma la acción tipificada en el artículo 282, una instrumentación de la conducta engañosa tipificada en el art. 248 y, por tanto, y en todo caso, un supuesto de tentativa de estafa ${ }^{93}$; en concreto, el sujeto activo lleva a cabo una conducta falsaria que es potencialmente engañosa y, por tanto, potencialmente lesiva a los intereses (económicos o patrimoniales) de aquellas personas a las que vaya dirigida ${ }^{94}$. Pero reparemos también en que se podría alegar una posible insuficiencia punitiva de esta calificación jurídica de la acción que ahora tipifica el art. 282 CP $1995^{95}$, en relación con la importancia creciente que la propia actividad publicitaria adquiere en el marco socioeconómico actual ${ }^{96}$, en el que cobran gran protagonismo, casi desmesurado, la empresa

90 Descarta el autor incluir entre tales bienes jurídicos la salud, basándose en que ésta ya encuentra una protección específica en otros tipos de peligro (como en los artículos $362.1 .3^{\circ}, 363.1$ y $4 \mathrm{CP} 1995$ ) que excluirían, como leyes preferentes, el artículo 282, así como en que "se caería en la paradoja de castigar el mayor desvalor de resultado con menor pena que la prevista para los delitos que ponen en peligro solamente la salud"; dicho lo cual hemos de advertir que la vía concursal quedaría abierta (Terradillos Basoco, J.Ma.: "El delito de publicidad engañosa”, en Ruiz Rodríguez, L.R. (Ed.), Sistema penal de protección del mercado y... ob. cit., pág. 75). En contra de esta opinión se postula Cugat Mauri, para quien, a través de la protección de la veracidad en este delito, se protegen igualmente el patrimonio y la salud, con lo que "debe descartarse la idea de que la protección penal se limita a los intereses patrimoniales de los consumidores, pues, la ausencia de una referencia expresa del tipo a la naturaleza patrimonial del perjuicio, permite sostener un mayor alcance del mismo, que permite abarcar los efectos perjudiciales de cualquier clase que la publicidad pueda causar al consumidor" (Cugat Mauri, M.: "La protección de los intereses colectivos: el caso...”, ob. cit., págs. $1.172-1.173)$.

91 Terradillos Basoco, J.Ma.: "El delito de publicidad engañosa", en Ruiz Rodríguez, L.R. (Ed.): Sistema penal de protección del mercado y... ob. cit., pág. 79.

92 Valle Muñiz, J.M.: “Artículo 282", ob. cit., pág. 1.279. No obstante, hay quien justifica el castigo de los fraudes publicitarios a través de una figura independiente porque, con anterioridad al tipo del art. 282 CP 1995, se ofrecía una protección parcial, "de modo indirecto, con los delitos contra la salud pública, las falsedades documentales, los fraudes alimentarios, etc., siendo insuficiente la tutela penal ofrecida" (Moreno y Bravo, E.: "Delitos relativos al mercado y...", ob. cit., pág. 293).

93 Así lo apunta Muñoz Conde, F.: Derecho Penal, ob. cit., pág. 443.

94 Y nada más, pues no se exige ni un acto de disposición económica por parte del sujeto pasivo como consecuencia de haber sido inducido a error por aquélla conducta ni, mucho menos, que éste sufra un perjuicio efectivo.

95 La tipificación expresa de la publicidad engañosa y, por tanto, la decisión del legislador en torno a su punición de forma independiente, se le antoja pertinente si al considerar que la conducta de publicidad engañosa, de ser castigada a través del delito de estafa, no pasaría del grado de tentativa, con la consiguiente reducción de la pena de prisión de seis meses a cuatro años prevista en el artículo 249 CP 1995 en uno o dos grados.

96 Pues hay quien califica las técnicas publicitarias como "insustituibles en una economía moderna y competitiva" (Martín Pallín, J.A.: "Fraudes a los consumidores en el ámbito de la Unión Europea", en AAVV: Delitos y cuestiones penales en el ámbito empresarial, II, Recoletos, 1999, pág. 131). 
de grandes dimensiones y la producción industrial en masa ${ }^{97}, \mathrm{y}$, correlativamente, tiene lugar un desarrollo de las relaciones comerciales a gran escala ${ }^{98}$. El Estado se ve entonces ante el riesgo de que su control sea reducido a la mínima expresión, con lo que "le urge" actuar con contundencia para evitarlo. El instrumento más recurrente y que, a su entender, ostenta las características necesarias para el logro de este objetivo es el "ius puniendi" o "derecho penal subjetivo", que detenta en absoluto monopolio. De este modo, frente a determinados poderes fácticos de naturaleza económica que buscan orientar los flujos del mercado en su propio beneficio, haciendo uso, entre otras técnicas, del "marketing" o publicidad, el Estado intenta oponer un intervencionismo que alcanza una dimensión de notoria importancia por el instrumento que emplea para ello ${ }^{99}$.

En relación con esta evidente manifestación concreta de la tendencia expansiva del Derecho Penal sobre la que tantísimo se ha escrito, y ante el hecho de que el marco que ofrecía el tipo de estafa se le antojaba al legislador insuficiente técnicamente para satisfacer las intenciones del Estado, en tanto, en concreto, la consideración individual del bien jurídico a proteger (el patrimonio como bien jurídico-penal individual), le impedía intervenir con la contundencia deseada que la sociedad misma parece demandarle ${ }^{100}$ para reprimir las conductas de publicidad engañosa (en tanto perturbadoras, en última instancia, del libre juego de fuerzas en el mercado), se ha visto el legislador en la necesidad de crear un bien jurídico-penal "intermedio o instrumental" (en el sentido que señalaba Terradillos Basoco) para superar o, más bien, para actuar dentro de los límites de la técnica del Derecho Punitivo.

Así resulta que, con la tipificación y posterior castigo de aquellas conductas que lesionen ese derecho-deber a una información publicitaria veraz, el Estado, en su faceta legisladora, intenta conseguir varios objetivos: $1^{\circ}$.- Pretende prevenir que los intereses económicos de los consumidores (sus patrimonios, al fin y al cabo) experimenten perjuicio alguno, lo cual no le interesa tanto desde su repercusión estrictamente individual como desde la más amplia (o, incluso, inmaterial): pretende lograr que la confianza de aquéllos en el mercado, en tanto demandantes, no se vea quebrada, con lo que tiende a asegurar que no dejen de concurrir al mismo, de modo que sigan "alimentando" los flujos económicos ${ }^{101} \cdot 2^{\circ}$.- Protege a aquellos otros sujetos económicos que concurren al merca-

97 Broseta Pont, M.: Manual de..., ob. cit., pág. 58.

98 Cugat Mauri, M.: "La protección de los intereses colectivos: el caso...”, ob. cit., pág. 1.168.

99 En el caso de la publicidad engañosa en concreto, y según apunta Terradillos Basoco, el legislador está adelantando la intervención penal al momento en que se produce una puesta en peligro de los intereses de los consumidores, "aceptando que las reglas de la libre competencia no son garantía plena de la mejor protección de los consumidores, siempre expuestos -incluso en condiciones de competencia- al abuso por parte de quienes, en situaciones muy próximas al monopolio, pueden organizar campañas publicitarias de grandes dimensiones" (Terradillos Basoco, J.Ma .: "El delito de publicidad engañosa", en Ruiz Rodríguez, L.R. (Ed.): Sistema penal de protección del mercado y...ob. cit., pág. 71).

100 Ello tiene que ver con la tan manida concepción de la sociedad actual como una "sociedad de riesgos", entendidos éstos como "situaciones globales de amenaza" (Beck, U.: La sociedad del riesgo. Hacia una nueva modernidad, Paidós, 1998, pág. 27) procedentes, fundamentalmente, de la propia acción humana. Ello ha dado lugar, en relación con el papel del Estado, a que "la promesa de seguridad (crezca) con los riesgos y (haya) de ser ratificada una y otra vez frente a una opinión pública alerta y crítica mediante intervenciones cosméticas o reales en el desarrollo técnico - económico" (Beck, U.: La sociedad del riesgo ..., ob. cit., pág. 26).

101 Sería aplicable aquí la tesis defendida por Hormazábal Malarée, y seguida y explicada por Miró Llinares, según la cual se viene a dar una relación teleológica entre el funcionamiento del sistema (configurado como bien jurídico macrosocial) y la protección de un bien jurídico individual, que es condición de existencia del mismo (como bien jurídico microsocial): de este modo "[...] no cabe duda de que atentar contra una condición de existencia del 
do como oferentes, de forma que no se vea conculcada la igualdad formal que la Norma Constitucional recoge como uno de los valores superiores del ordenamiento (relacionándola con el ejercicio del derecho a la libertad de empresa $)^{102}$.

En síntesis, como acertadamente apunta Ortiz de Urbina Gimeno, no sólo es que la libre competencia tienda a asegurar "precios más bajos y/o bienes y servicios de mejor calidad, con el consiguiente beneficio para los consumidores" desde el punto de vista patrimonial, sino que, además, "la competencia también protege los intereses de las personas físicas y jurídicas que proveen bienes y servicios y los del mayor consumidor de bienes y servicios, la Administración pública, y esto revierte en los consumidores individuales en forma de productos más baratos y de un mejor servicio público (o del mismo a menor coste y necesidad de menos impuestos para financiarlo)" ${ }^{103}$.

Puede concluirse, pues, en la aparente conveniencia político-criminal de tipificar de forma autónoma los comportamientos constitutivos de publicidad engañosa, $1^{\circ}$ ) por la importancia de los intereses sociales en juego y dignos de ser protegidos (el mercado, la competencia económica, y los intereses económicos de los consumidores, esto es, en última instancia, sus patrimonios), pues su relevancia social, incluso específicamente constitucional (principio de necesidad de protección), está fuera de toda duda conforme a lo aquí expuesto, así como, en lógica consecuencia, también puede concluirse en la aparente legitimidad material del Derecho Penal para hacerlo, $2^{\circ}$ ) tanto desde el punto de vista de la intervención mínima (sólo se castiga una de las más graves manifestaciones de la publicidad calificada como ilícita en nuestro ordenamiento, para cuya persecución existen otras vías distintas de la penal), $3^{\circ}$ ) como desde el punto de vista de la concreta proporcionalidad de tal intervención punitiva ${ }^{104}$.

En todo caso, como he sostenido en otros trabajos, tras la constatación de esa apariencia de legitimidad material, es imprescindible "saber si la Política Criminal funciona" a través de su evaluación ${ }^{105}$. Esto es, ha de evaluarse empíricamente si la política criminal que el legislador español adoptó en 1995 para tutelar los intereses sociales relacionados con la publicidad engañosa, tal y como han sido expuestos en este trabajo, logra o no los

sistema - en este caso el patrimonio - afecta al funcionamiento del mismo y, por tanto, mediante la protección del bien jurídico individual necesario para el sistema -de libre mercado-, se protege éste de forma indirecta" (Miró Llinares, F.: La protección penal de la propiedad intelectual..., ob. cit., pág. 253, citando a Hormazábal Malarée, H.: "Los delitos socioeconómicos, el bien jurídico, el autor, su hecho y la necesaria reforma del sistema penal español", en AAVV: Hacia un derecho penal económico europeo. Jornadas en honor del profesor Klaus Tiedemann, Boletín Oficial del Estado, 1995, pág. 195).

102 No obstante, hay que tener en cuenta que la propia utilización del Derecho Penal exige proceder bajo la premisa del respeto de ciertas libertades, entre ellas, precisamente, la de aquel sujeto que incurre en publicidad engañosa a ejercer también su derecho a la libertad de empresa. En este sentido ha apuntado acertadamente Cugat Mauri que "la protección de la veracidad en el ámbito de las relaciones comerciales no puede comportar la imposición al empresario de unos deberes de información que perviertan la función o desnaturalicen los cometidos propios de la publicidad, puesto que sería tanto como negar el derecho a desarrollarla", derecho que se entiende incluido en el ejercicio mismo de la libertad de empresa (Cugat Mauri, M.: "La protección de los intereses colectivos: el caso...", ob. cit., pág. 1.176).

103 Ortiz de Urbina Gimeno, Í.: "Problemas (reales y ficticios) y necesidad de la protección penal de la competencia en España: el caso de la fijación de precios”, en Hernández Plasencia, J.U. (Coord.): La intervención penal en la protección de los intereses económicos de los consumidores, Marcial Pons, 2020, pág. 263.

104 Sánchez Lázaro, F.G.: "Determinación, proporcionalidad y pena: sobre el ejemplo del delito de publicidad engañosa (art. 282 CP)", en Hernández Plasencia, J.U. (Coord.): La intervención penal en la protección de los intereses económicos de los consumidores, Marcial Pons, 2020, págs. 395-403.

105 Zúñiga Rodríguez, L.C.: Política Criminal, Colex, 2001, pág. 174. 
objetivos pretendidos (eficacia), si las medidas normativas que conlleva son o no efectivamente cumplidas por los ciudadanos (efectividad) y si hace lo anterior o no con el menor coste posible (eficiencia). Esta comprobación podrá ser objeto de un posterior trabajo que complemente el aquí presentado.

\section{BIBLIOGRAFÍA}

Bajo Fernández, M. y Bacigalupo Saggese, S. Derecho penal económico, Centro de Estudios Ramón Areces, 2001 ( $1^{\text {a }}$ edición).

Baylos Corroza, H. Tratado de Derecho industrial, Civitas, Madrid, 1993 (2ª edición).

BECK, U. La sociedad de riesgo. Hacia una nueva modernidad (traducido por Jorge Navarro, Daniel Jiménez y María Rosa Borrás), Paidós, 2001.

Bourgoigne, T. Elementos para una teoría del Derecho de Consumo (traducido por GABISER), Gobierno Vasco, 1994.

Broseta Pont, M. Manual de Derecho Mercantil, Tecnos, 1994 (10ª edición).

Carrasco Andrino, Ma.M. La publicidad engañosa y el Derecho Penal (una aproximación al tipo del artículo 282 del C.P.), Revista General de Derecho, 2000.

Cases Pallarés, Ll. Derecho administrativo de la defensa de la competencia, Marcial Pons, 1995.

Choclán Montalvo, J.A. "El delito publicitario en el nuevo Código Penal”, en Actualidad Jurídica Aranzadi, núm. 256, 1996.

Chomsky, N. y Ramonet, I. Cómo nos venden la moto, Icaria, 2001.

CONESA, F. Libertad de empresa y Estado de Derecho, Rialp, 1978.

Cugat Mauri, M. "La protección de los intereses colectivos: el caso del delito publicitario", en Quintero Olivares, G. y Morales Prats, F. (Coords.): El nuevo Derecho Penal Español. Estudios Penales en Memoria del profesor José Manuel Valle Muñiz, Aranzadi, 2001.

Deane, P. La Primera Revolución Industrial (traducido por Jordi Solé-Tura), Península, 1998 (9a edición).

De Castro y Bravo, F. "Notas sobre las limitaciones intrínsecas de la autonomía de la voluntad. La defensa de la competencia. El orden público. La protección del consumidor”, en Anuario de Derecho Civil, 1982.

De la Cuesta Aguado, P.M. "Protección penal de los consumidores", en Revista General de Derecho, núm. 668, 2000.

Del Rosal Blasco, B. Los delitos societarios en el Código Penal de 1995, Tirant lo Blanch, 1998.

Demetrio Crespo, E. "A propósito del bien jurídico en el delito publicitario tipificado en el art. 282 del Código Penal español (una contribución a partir de una 'hermenéutica valorativa')", en Revista de Derecho y Proceso Penal, núm. 12, 2004.

Entrena Cuesta, R. "El principio de libertad de empresa", en Garrido Falla, F. (Dir. y Coord.): El modelo económico en la Constitución Española (I), Instituto de Estudios Económicos, 1981.

Fernández Albor, A. "Prólogo", en Lorenzo Salgado, J.M. Las drogas en el ordenamiento penal español, Bosch, 1978.

Font Galán, J.I. Constitución económica y derecho a la competencia, Tecnos, 1987.

Franceschelli, R. Studi e capitoli sul diritto della concorrenza, Giuffrè, 1970.

Galán Corona, E. Acuerdos restrictivos de la competencia, Montecorvo, 1977.

Garrigues, J. La defensa de la competencia mercantil, Sociedad de Estudios y publicaciones, 1964.

GonzÁlez Rus, J.J. Los intereses económicos de los consumidores. Protección penal, Instituto Nacional del Consumo, 1986.

GonZÁLez Rus, J.J. "Delitos contra el patrimonio y contra el orden socioeconómico (VIII)", en Cobo del Rosal, M. (Dir.): Curso de Derecho penal. Parte Especial (I), Marcial Pons, 1996. 
GonzÁLEz Rus, J.J. “Delitos contra el patrimonio y contra el orden socioeconómico (I)”, en Cobo del Rosal, M. (Dir.): Compendio de Derecho penal español (Parte Especial), Marcial Pons, 2000.

Hefendehl, R. “¿Debe ocuparse el Derecho Penal de riesgos futuros? Bienes jurídicos colectivos y delitos de peligro abstracto" (traducido por Eduardo Salazar Ortuño), en Revista Electrónica de Ciencia Penal y Criminología, núm. 4, 2002.

Hernández Plasencia, J.U. "El delito publicitario”, en Actualidad Penal, núm. 48, 1997.

Hobsbawm, E.J. Industria e Imperio. Una historia económica de Gran Bretaña desde 1750 (traducido por Gonzalo Pontón), Ariel Historia, 1982 (2 edición).

HormazÁbal Malarée, H. "Los delitos socioeconómicos, el bien jurídico, el autor, su hecho y la necesaria reforma del sistema penal español", en AAVV: Hacia un derecho penal económico europeo. Jornadas en honor del profesor Klaus Tiedemann, Boletín Oficial del Estado, 1995.

KLEPPNER, O. Publicidad (traducido por Georgina Greenham del Castillo), Prentice Hall, 1994 (12ª edición).

LAMPE, E.J. "La protección jurídico-penal de la competencia económica en el Anteproyecto del Código Penal español de 1983”, en Barbero Santos, M. (Ed.): Los delitos socio-económicos, Universidad Complutense de Madrid, 1985.

LEón, J.L. Los efectos de la publicidad, Ariel Comunicación, 1996.

López Garrido, D. y García ArÁn, M. El Código Penal de 1995 y la voluntad del legislador, Eurojuris, 1996.

Linde Paniagua, E. Introducción al sistema económico en la Constitución Española, Cometa, 1987.

Luzón PeÑA, D.M. "El delito publicitario en el nuevo Código Penal de 1995”, en Cartas CEDEF, núm. $1,1996$.

Macías EsPejo, B. El delito de publicidad engañosa, Dykinson, 2016.

Mapelli Caffarena, B. El delito de publicidad fraudulenta, Tirant lo Blanch, 1999.

Martín Pallín, J.A. "Fraudes a los consumidores en el ámbito de la Unión Europea”, en AAVV: Delitos y cuestiones penales en el ámbito empresarial, II, Recoletos, 1999.

Martínez PÉrez, C. "El delito de publicidad engañosa en el Anteproyecto de Código Penal español de 1992", en AAVV: Hacia un derecho penal económico europeo. Jornadas en honor del profesor Klaus Tiedemann, Boletín Oficial del Estado, 1995.

Massaguer Fuentes, J. Comentario a la Ley de Competencia Desleal, Civitas, 1999.

Mata y Martín, R.M. Bienes jurídicos intermedios y delitos de peligro, Comares, 1997.

Menéndez MenÉndez, A. La competencia desleal, Real Academia de Jurisprudencia y Legislación, 1988.

Miró Llinares, F. La protección penal de la propiedad intelectual en la sociedad de la información, Dykinson, 2003.

Molina Blázquez, C. Protección jurídica de la lealtad en la competencia, Montecorvo, 1993.

Moreno y Bravo, E. “Delitos relativos al mercado y a los consumidores”, en Bacigalupo Zapater, E. (Dir.): Curso de Derecho Penal Económico, Marcial Pons, 1998.

Moreno y Bravo, E. El delito de publicidad falsa. El artículo 282 del CP 1995, la protección penal de los consumidores frente a la actividad publicitaria falaz, Bosch, 2001.

Morillas Cueva, L. "Reflexiones sobre el Derecho Penal del futuro", en Revista Electrónica de Ciencia Penal y Criminología, núm. 4, 2002.

Muñagorri Laguía, I. La protección penal de los consumidores frente a la publicidad engañosa (Art. 282 del Código Penal), Comares, 1998.

Muñoz Conde, F. Derecho Penal. Parte Especial, Tirant lo Blanch, 1996 (11 a edición).

Muñoz Cuesta, J. "Publicidad engañosa: una figura de contornos poco definidos que dificultan su aplicación”, en Revista Aranzadi Doctrinal, núm. 1, 2010.

Ortiz de Urbina Gimeno, Í. "Problemas (reales y ficticios) y necesidad de la protección penal de la competencia en España: el caso de la fijación de precios”, en Hernández Plasencia, J.U. (Coord.): $L a$ intervención penal en la protección de los intereses económicos de los consumidores, Marcial Pons, 2020. 
PÉrez del Valle, C. “Introducción al Derecho Penal Económico”, en Bacigalupo Zapater, E. (Dir.): Curso de Derecho Penal Económico, Marcial Pons, 1998.

PÉrez Ferrer, F. “Aspectos dogmáticos y político-criminales de la protección del mercado, la competencia y los consumidores en el Derecho penal español”, en Morillas Cueva, L. (Dir.): Derecho y consumo. Aspectos penales, civiles y administrativos, Dykinson, 2013.

Portero Henares, M. El delito publicitario en el Código Penal español, Tirant lo Blanch, 2004.

Puente ABA, L.Ma " "El delito de publicidad falsa: apuntes históricos y de Derecho comparado", en Ruiz Rodríguez, L.R. (Ed.): Sistema penal de protección del mercado y de los consumidores. Actas del II Seminario Internacional de Derecho Penal Económico (Jerez, diciembre 2000), Tirant lo Blanch, 2002.

Puente ABA, L.M a . Delitos económicos contra los consumidores y delito publicitario, Tirant lo Blanch, 2002.

Puente AbA, L.M . "Comentario a las primeras sentencias del delito de publicidad falsa (art. 282 del CP)", en Revista de Derecho Penal y Criminología, núm. 14, 2004.

Quintero Olivares, G. (y Morales Prats, F. (Colab.)): Parte General del Derecho penal, Aranzadi, 2005 ( $1^{\text {a }}$ edición).

RODRÍGUEZ DE QuiÑONES Y DE TORRES, A. "La protección del consumidor en la Constitución española de 1978. Notas para un debate", en Revista General de Derecho, núms. 678 - 679, 2001.

Rodríguez Ramos, L. y De la Cuesta Rute, J.Ma. "El delito publicitario”, en Autocontrol, núm. $26,1998$.

Rubio LARA, P.Á. Parte Especial del Derecho penal económico (una aproximación al estado de la cuestión en la doctrina y jurisprudencia españolas), Dykinson, 2006.

SÁnchez García de PAz, I. "El nuevo delito publicitario (art. 282 del Código penal)”, en Actualidad Penal, núm. 1, 1997.

SÁnchez Guzmán, J.R. Breve historia de la publicidad, Pirámide, 1973.

SÁNCHEZ LÁzARO, F.G. "Determinación, proporcionalidad y pena: sobre el ejemplo del delito de publicidad engañosa (art. 282 CP)”, en Hernández Plasencia, J.U. (Coord.): La intervención penal en la protección de los intereses económicos de los consumidores, Marcial Pons, 2020.

Santaella López, M. Derecho de la publicidad, Civitas, 2003 (1ª edición).

Sierra LóPez, Ma .V. Análisis jurídico-penal de la publicidad engañosa en Internet, Tirant lo Blanch, 2003.

Sierra LóPez, Ma.V. "El delito de publicidad engañosa en la jurisprudencia”, en Muñoz Conde, F.J. (Coord.): Problemas actuales del Derecho Penal y de la Criminología: Estudios Penales en memoria de la Profesora Dra. María del Mar Díaz Pita, Tirant lo Blanch, 2008.

Soler Masota, P. "Panorama del Derecho de la Publicidad en la Unión Europea", en Actas de Derecho Industrial, núm. XX, 1999.

Soriano García, J.E. Derecho público de la competencia, Marcial Pons, 1998.

TAmarit Sumalla, J.Ma " "La tutela penal de los intereses de los consumidores en la actividad publicitaria: problemas fundamentales”, en Cuadernos de Política Criminal, núm. 41, 1990.

Terradillos Basoco, J.Ma "El delito de publicidad engañosa”, en Ruiz Rodríguez, L.R. (Ed.): Sistema penal de protección del mercado y de los consumidores. Actas del II Seminario Internacional de Derecho Penal Económico (Jerez, diciembre 2000), Tirant lo Blanch, 2002.

Terradillos Basoco, J.Ma "Peligro abstracto y garantías penales", en Quintero Olivares, G. y Morales Prats, F. (Coords.): El nuevo Derecho Penal Español. Estudios Penales en Memoria del profesor José Manuel Valle Muñiz, Aranzadi, 2001.

ToRío López, Á. "Reflexión sobre la protección penal de los consumidores”, en AAVV: Estudios sobre el Derecho de consumo, Fundación Iberdrola, 1991 (1ª edición).

TOYNBeE, A.J. Lectures on the Industrial Revolution in England, Kessinger, 2010.

Uría, R. y Menéndez Menéndez, A. Curso de Derecho Mercantil (I), Civitas, 2006 (2ª edición).

Valle MuñIz, J.M. “Artículo 282”, en Quintero Olivares, G. (Dir.): Comentarios al Nuevo Código Penal, Aranzadi, 1996 (1 $1^{\text {a }}$ edición).

ZúÑIga Rodríguez, L.C. Política Criminal, Colex, 2001. 